\title{
State spatial practices and uneven development: Flexible rescaling in Appalachia
}

\author{
Jacquelyn Jordon Core \\ West Virginia University
}

Follow this and additional works at: https://researchrepository.wvu.edu/etd

\section{Recommended Citation}

Core, Jacquelyn Jordon, "State spatial practices and uneven development: Flexible rescaling in Appalachia" (2010). Graduate Theses, Dissertations, and Problem Reports. 4576.

https://researchrepository.wvu.edu/etd/4576

This Dissertation is protected by copyright and/or related rights. It has been brought to you by the The Research Repository @ WVU with permission from the rights-holder(s). You are free to use this Dissertation in any way that is permitted by the copyright and related rights legislation that applies to your use. For other uses you must obtain permission from the rights-holder(s) directly, unless additional rights are indicated by a Creative Commons license in the record and/ or on the work itself. This Dissertation has been accepted for inclusion in WVU Graduate Theses, Dissertations, and Problem Reports collection by an authorized administrator of The Research Repository @ WVU.

For more information, please contact researchrepository@mail.wvu.edu. 


\title{
State Spatial Practices and Uneven Development: Flexible Rescaling in Appalachia
}

\author{
Jacquelyn Jordon Core \\ Dissertation submitted to the \\ Eberly College of Arts and Sciences \\ at West Virginia University \\ in partial fulfillment of the requirements for the degree of
}

\author{
Doctor of Philosophy \\ in \\ Geography
}

\author{
Graduate Committee \\ Dr. Robert Hanham, Ph.D (Chair) \\ Dr. Richard Hoch, Ph.D \\ Dr. Jamie Jacobs, Ph.D \\ Dr. Ken Martis, Ph.D \\ Dr. Brent McCusker, Ph.D
}
Department of Geology and Geography
Morgantown, West Virginia
2010

Keywords: State Spatial Practices, Uneven Development, Flexible Rescaling, Dispossession, Eminent Domain, Appalachia 


\section{ABSTRACT \\ State Spatial Practices and Uneven Development: Flexible Rescaling in Appalachia}

Jacquelyn Core

Geographic theories regarding uneven development, including Neil Smith’s convergence of Marxist theory and spatial development and David Harvey's development of scalar fix and later conceptual development of the process of capital accumulation, historically have focused primarily on how and why uneven development occurs. Research to date has provided only a cursory examination of what role, if any, the state plays in impacting uneven development, has not endeavored to characterize the state as an active, purposeful spatial player in the process of uneven development, and has not conceptualized how the state impacts uneven development through spatial practices, if the state does in fact do so. This dissertation attempts to fill that gap in the literature by examining the state's role in uneven development and theorizing that the state plays an active spatial role in impacting uneven development to benefit capital interests. The dissertation conceptually develops and illustrates a new theory of flexible rescaling which builds on the prior work of Smith and Harvey and attempts to elucidate the under conceptualized role of the state. Through flexible rescaling the state can be seen actively engaged in the redistribution of internal power within the confines of an already established but inherently flexible fixed network of power, acting as a committee serving the interests of capital. This dissertation uses dialectics as its methodology, both to develop the conceptual framework and to illustrate the state's use of it in a more concrete context where the state rescales power upward or downward or rescales power laterally to facilitate spatial change while fostering consent and/or overcoming any obstacle to spatial change. The dissertation uses examples from Appalachia of land practices resulting in uneven development brought about by state spatial practices that benefit capital to illustrate the theoretical development of flexible rescaling. 


\section{ACKNOWLEDGEMENTS}

This academic work would have been impossible without the love, encouragement, and support of my parents, Jim and Candy Jordon, and the tolerance of my children, Jackson and Preston. The four of them, individually and collectively, form the best and most supportive family any researcher or writer could want or have. They have been inspiring and have never doubted my ability, or questioned my desire, to conceptually develop the theory just a little more. They never complained about my reading or re-reading of one more article or one more book. Their patience while I was reading and writing was interminable. I thank all four of you. My success in this endeavor, and in life, is credited to you, possible because of you, and done for you. To Jackson and Preston-Never doubt your ability to achieve anything to which you set your mind. Anything is possible.

To my friends who have supported me: to Janet Armistead and Rachel Welsh de Iga who said “why not?” to the crazy idea of me getting a second doctorate, to Hallie Chillag who helped me get this process started, to Lynn Rausch who travelled the world with me when I needed a break, and to Deva Solomon who helped with countless technical difficulties and who prodded over and over "shouldn't you be working on your dissertation?" Thank you to each of you. You are wonderful and supportive friends, and I hope in some way my friendship has repaid or will repay you.

I would be remiss not to thank Neil Smith and David Harvey for their theoretical brilliance and for creating, or leaving, a theoretical gap I was privileged enough to help fill. I am grateful to both of them every day for such a wonderful gift. I am also thankful to my committee and to the WVU Department of Geology and Geography generally for questions and input and suggestions and time, in the exception of one person who I need to thank separately-my committee chair.

Like any researcher or writer, the task of enumerating those who impacted the research extends far beyond the simple listing of one's academic colleagues and one's relatives. Instead, the process of researching and writing, and in this case conceptual and theoretical development of spatial practices theory, creates and changes spaces itself. My dissertation chair, Dr. Robert Hanham, along with his lovely wife Alison, are the real reason this dissertation is what it is. He was always challenging me to make it better, to think about it differently, and to remain devoted to it. I have never met anyone with a greater capacity for conceptual and theoretical discussion, development, and thought, and I have never met anyone more devoted to students and the academic and personal development of students. But more than all that, although Dr. Hanham and I started as academic colleagues, our personal spaces were altered by this process. Robert and Alison became like family to me through this process, and as much as anything I thank them for their love, patience, and understanding as I thank my own family. Everyone should be so blessed as I am to have found two people so invested in their success, so supportive of their life endeavors, and so giving of time, energy, and intellectual capital. Robert, we have always thought that life is about connections, and I am so pleased that this dissertation has connected me to you and Alison. I wish you both the best in life, I thank you, and I hope the end of this road does not find us diverging, because losing connection to you both would be a terrible personal loss. 


\section{TABLE OF CONTENTS}

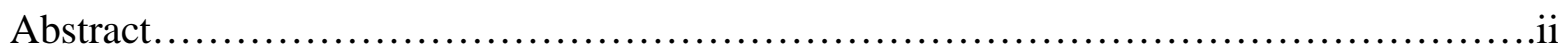

Acknowledgements................................................................

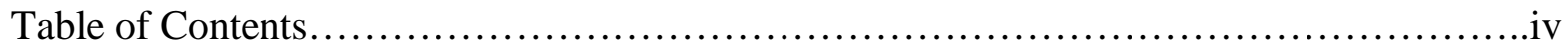

Chapter 1: On Developing a New Conceptual Framework..............................1

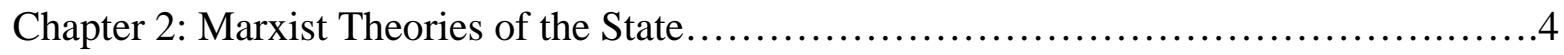

$2.1 \quad$ Milliband's State.....................................................

2.2 Poulantzas' State....................................................

2.3 Gramsci's Contribution............................................9

Chapter 3: Uneven Development and the State....................................13

3.1 Capital Accumulation Strategies....................................16

State Spatial Practices..............................................20

3.2.1 Harvey’s Grid of Spatial Practices............................20

3.2.2 Flexible Rescaling..........................................22

Chapter 4: Geographic Theorizations to Date Regarding the State and Uneven Development.............................................24

4.1 The Institutional and Functional Roles of the State........................24

4.2 Brenner, Smith, and Harvey on the State and Uneven Development........28

4.2.1 Brenner on the State's Role in Uneven Development...............29

4.2.2 Smith on the State's Role in Uneven Development.................31

4.2.3 Harvey on the State's Role in Accumulation Strategies and Uneven Development.............................................34

Chapter 5: Ollman’s Dialectical Method..........................................37 
$5.1 \quad$ Four Dialectical Relations...............................................

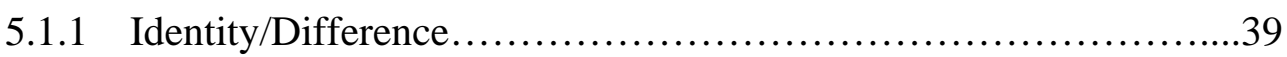

5.1.2 Interpenetration of Opposites....................................39

5.1 .3 Quantity/Quality................................................40

5.1.4 Contradiction.........................................................40

5.2 Three Modes of Abstraction...........................................43

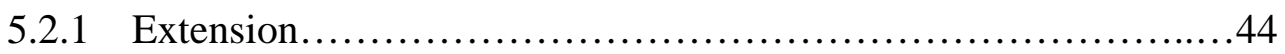

5.2.2 Level of Generality ............................................ 45

5.2.3 Vantage Point.....................................................48

5.3 Examples of the Use of Dialectics in Geography........................49

Chapter 6: A New Examination of the State's Role in Uneven Development................55

Chapter 7: State Flexible Rescaling and Land Acquisition: Examples from Appalachia...58

7.1 Land Acquisitions Illustrating Flexible Rescaling: Accumulation by Dispossession and the Transition to Early Industrialism..................59

7.2 Land Acquisitions Illustrating Flexible Rescaling: Eminent Domain........64

7.2.1 TrAIL and High Voltage Transmission Lines in Appalachia.........65

7.2.2 Mountaintop Removal in Appalachia..............................77

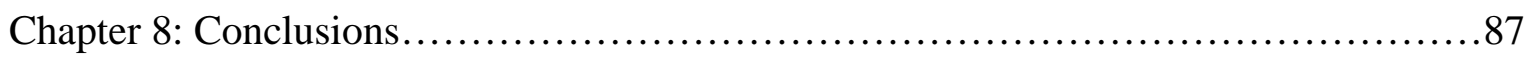

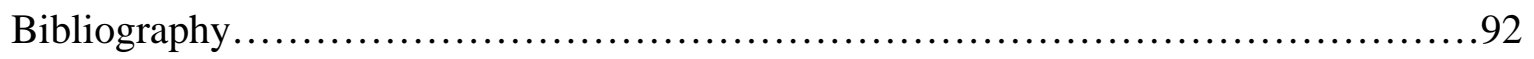




\section{Chapter 1 \\ Introduction}

"The dialectic is critical, because it helps us to become critical of what our role has been up to now." Bertell Ollman, Dialectical Investigations, 1993, p. 19.

To date the state's spatial role in uneven development has remained somewhat under-theorized. Geographic research to date has failed to conceptually examine the state's spatial role in uneven development in terms of the relationship between capital accumulation strategies and state spatial practices. Theories of scaling and rescaling are well developed. Researchers have recognized that the state can scale and rescale, but they have failed to view that rescaling as an active spatial practice which the state employs to affirmatively impact uneven development to benefit capital.

This ability of the state to scale and rescale comes with an inherent flexibility which has been built into the state system. Laws and regulations governing the operations of states have mechanisms in place to allow rescaling through what has already been recognized as a downward shift or devolution of power. (Smith, 2003). The corresponding ability of states to shift power upward has not been as thoroughly explored. When we recognize the ability to shift power and responsibility upward and downward through the scales of the state or laterally within the state system in place and without formal restructuring, within the context of accumulation strategies, the new concept of flexible rescaling emerges.

To fully examine and understand this concept of flexible rescaling we need to first recognize the dependency between Harvey's two forms of capital accumulation strategies. That is, we must recognize, as Harvey does, that without accumulation by dispossession there could be no accumulation by expanded reproduction. It is this need to shift between forms of capital accumulation that creates a need within the state to flexibly rescale. Power must be shifted to 
allow the regulation and oversight necessary to coordinate the transition between forms of capital accumulation. The first capital accumulation strategy is accumulation by expanded reproduction and the second is accumulation by dispossession. (Harvey, 2003). By examining the connections between Harvey's two forms of capital accumulation, we can recognize state rescaling itself as a spatial practice. As the state purposefully shifts power to flexibly rescale, capital shifts between forms of accumulation, thereby resulting in uneven development. The two processes are closely intertwined: without the ability to flexibly rescale and the inherent power shifts within the state which accompany flexible rescaling capital would be unable to transition between accumulation by dispossession and accumulation by expanded reproduction, which transition ultimately results in continued capital growth and expansion.

Smith and Harvey have both discussed at length the need by capital to continually expand as well as the ways capital attempts to achieve that goal of continued expansion. (e.g. Smith, 1992; Harvey, 2005). They have not examined the state's role in facilitating that expansion through rescaling. Harvey has recognized two distinct forms of capital accumulation, but he has not fully developed how the transitions and connections between them are driven by the state's role in actively rescaling power. This dissertation will develop the new concept of flexible rescaling as a state spatial practice and will provide concrete examples of the state's flexible rescaling with regard to land acquisitions in Appalachia. The dissertation will examine how the state uses spatial practices to impact uneven development to benefit capital; that is, it will examine how the state flexibly rescales.

In this more concrete context, in Appalachia, this flexible rescaling can be seen in its simplest form when examining state sponsored or sanctioned land acquisitions. The concept can be illustrated by examining land acquisitions in Appalachia in two time periods. First, 
flexible rescaling can be seen during the early transition from self sufficient farming to dependency on capital employment through industrialization when the state changed scales to allow accumulation by dispossession to occur as a necessary precursor to accumulation by expanded reproduction. Second, flexible rescaling can also be seen in Appalachia though modern eminent domain practices sanctioned by the state which have begun to take private property for "public use" and later for "public benefit" - primarily used here to demonstrate the concept of flexible rescaling itself at work.

The dissertation summarizes Marxist theories of the state on which the dissertation is based and summarizes the concept of uneven development as it has been developed to date and as it is assumed herein. Geographic research to date regarding the two forms of capital accumulation strategies and regarding scaling and rescaling is reviewed. Geographical theorizations to date on the state's role in uneven development are also reviewed, summarizing the traditional views of the state and its spatial practices and reviewing work that already establishes some link between state spatial practices and capital accumulation, including research by Brenner, Smith, and Harvey. The dialectical method is explained to facilitate an understanding of the how the concept of flexible rescaling was developed here. A contribution to the geographic literature on the state's active spatial role in uneven development is made in developing of the new concept of flexible rescaling. Flexible rescaling will be illustrated through two case studies involving land acquisitions in Appalachia: the early transition from subsistence agriculture to industrialism and the later, more modern, example of how flexible rescaling continues to be used by the state through eminent domain. 


\section{Chapter 2 \\ Marxist Theories of the State}

This dissertation uses a Marxist view of the state. Therefore, an examination of Marxist theorizations of the state is helpful to an understanding of this research. Such theorizations are hallmarked by their treatment of the state as "the committee for managing the affairs of capitalists." (Ollman, 1993, p. 89). As a result, Marxists never see the state as neutral. The later examined example of eminent domain as illustrative of the conceptual development of flexible rescaling is clearest when we recognize, as a precursor to the conceptual development, that the state acts primarily on behalf of and manages first and foremost the interests of capital. Marxist state theorists always see the state as acting this way: on behalf of capital's interests.

"In Marx's theory of politics, the capitalist state is conceived of as a complex social relation of many different aspects, the main ones being political processes and institutions, the ruling class, an objective structure of political/economic functions, and an arena for class struggle." (Ollman, 1993, p. 89). Different theorists focus on different aspects in theorizing the state. Ollman refers to these as "one-sided relations." (Ollman, 1993, p. 89). Generally, Lenin and Ralph Milliband are associated with instrumental Marxism and Nicos Poulantzas is associated with structural Marxism, although Poulantzas later refined his own theory of the state to define the state as an arena for class struggle. Antonio Gramsci is regarded as characterizing the state as hegemonic. Bertell Ollman is regarded as characterizing the state primarily as an illusory community that forms from social relations.

Each one-sided interpretation of the state referred to here "brings out something important about the capitalist state- about its appearance, structure, functioning (including contradictory functioning), ties to the rest of capitalism, and potential for change- just as it hides and distorts much else." (Ollman, 1993, p. 90). Each one-sided relation "represent[s] . . . 
different tendencies inside the state relation," thus magnifying Marx's focus on internal relations. (Ollman, 1993, p. 91). Brief discussions of each of the primary state theorists whose theories are relied upon to any extent in this dissertation, including their differences, are contained below. However, it is important to note before proceeding that none of the Marxist theorists who will be discussed here is responsible for an incorrect Marxist theorization of the state. Rather, their theorizations evidence the dialectical method and are illustrative of the different abstractions of extension, level of generality, and vantage point discussed in more detail below, when discussing the dialectical method. Regardless of the specific theorist relied upon, capital's interests remain at the forefront of rationale for state activity. Herein, primary reliance is made on the Marxist state theory of Ralph Milliband to explain state action in the context of capital benefit.

\section{$2.1 \quad$ Milliband's State}

Ralph Milliband's seminal work on the Marxist state is "The State in Capitalist Society." (Milliband, 1969). Milliband is regarded as an instrumentalist, or Leninist Marxist, because he refers to the state as an "instrument" or "tool" available for use by capital to ensure the maintenance of conditions of uneven development beneficial to capital. This view of the state is primarily best suited to the development of the concept of flexible rescaling, because it demonstrates and recognizes both the state's volitional actions as well as capital's reliance on the state for those actions as a means to secure conditions of uneven development favorable to capital.

For Milliband, the state is operated by the ruling capitalist class, the bourgeoisie, who either directly control the means of production or who are aligned socially with those who control the means of production. (Milliband, 1969). As a result, it makes sense that the state acts on capital's behalf. Milliband also recognizes the simple economic power of the bourgeoisie 
and its influence on state action. Those in power within society are in a better position to impact state action. They are more educated, they have more resources to devote to impacting or influencing state action, and they are operating within society on the same level as the ruling elite within the state. These ruling class members who control the functions of the state, therefore, typically act in the best interest of those who control the means of production, their peers.

The formal lobby system in the United States, whereby capital interests are allowed to pay individuals and firms with specialized knowledge about their particular industry to attempt to influence those within the state exemplifies the connection between the state and the bourgeoisie. The state elite and the capital elite operate in parallel frameworks within the state and capitalist society. Their interests in that regard are aligned in a way that gives natural inclination to the state elite to adopt the interests of the capital elite. However, Milliband also addressed state power as requiring the legitimacy of the workers within society. (Milliband, 1969).

In terms of the requirement of legitimacy, Milliband argued that the state uses its influence on behalf of the bourgeoisie through education, propaganda, and regulation to coopt the working class into the system of capitalism, despite the system's actual failure to serve the best interests of those workers. (Milliband, 1969). Milliband seems to suggest that given the relative potential power of workers, including their shear numerosity, the political system expected to result would be one that advantages the interests of the worker over the bourgeoisie. Milliband recognized, however, that despite this relative potential power the resulting system will almost always mirror the system sought by the bourgeoisie. Milliband explains this seeming anomaly by noting that alliances of the bourgeoisie with those in power, and the economic power 
of those members of the bourgeoisie whose interests are typically advanced, result in a political system which ultimately is counterintuitive. He sees the system as theoretically capable of advantaging the worker but unlikely to do so in the end. That is, regardless of the democratic nature of a given state and regardless of the numerosity of workers, because of the power of the bourgeoisie, the bourgeoisie's interests will control. The door remains open to research into the bourgeoisie's control of media and propaganda in securing this legitimation and how that control is fostered by the state as a secondary aspect of flexible rescaling.

\section{$\underline{2.2}$ Poulantzas' State}

While Milliband and Poulantzas agree for the most part about the Marxist state, Poulantzas is commonly regarded as a structural Marxist. Ollman notes that the "state is said to be an instrument of the ruling economic class; but Marx also treats [the state] as a set of objective structures that respond to the requirements of the economy." (Ollman, 1993, p. 67)(emphasis added). Therefore, it can be said, under Ollman's recognition, that Milliband and Poulantzas both arguably correctly articulate Marx's conception of the state. The two simply focus on different aspects or internal relations within Marx's conceptualization of the state. Ollman posits that "many similar, apparently contradictory positions taken in Marx's writings ... are due to different abstractions of vantage point. The same relation is being viewed from different sides, or the same process from its different moments." (Ollman, 1993, p. 67-8).

To the extent that any distinction does exist, Poulantzas distinction from Milliband arises from his position that, instead of the state being an instrument of control and domination over workers used by the bourgeoisie, Poulantzas believes that the state is actually socially formed by the bourgeoisie. (Poulantzas, 2001). His Marxist state theory is premised on integration of the state with bourgeoisie society. He sees the bourgeoisie as integral to the state 
and as a part of the state rather than as controlling or using the state. For Poulantzas, at least in his early writings, a non-capitalist state could not exist within a capitalist economic system. His theory deprives workers of the ability to control the system with its current incarnation by meshing the bourgeoisie with the state in such a way as to make it impossible for workers to even garner any influence over the state. To impact the system workers would have to restructure the system itself to be a non-capitalist state. As a result, Milliband's state theory better encompasses the conceptual development of flexible rescaling. Milliband's theory could allow power at times to be seated with the worker, instead of at all times being seated within the state.

Anyone who rises to power in the state as Poulantzas sees it will assume the cloak of the bourgeoisie. The state theory Poulantzas adopts relies on the appearance of "relative autonomy," whereby workers are not perceived to be directly controlled by those who retain the means or production, but, rather, the perception of workers is that the state is autonomousseparate and apart from the bourgeoisie, when in fact it is not. (Poulantzas, 2001). Whereas, Milliband's conceptualization of the state as an instrument of capital would allow workers to assume power within the state and, at least theoretically, change the nature of the state within a capitalist society, Poulantzas would require revolution to achieve this goal as the working class would have to both assume power and achieve the political and economic backing within society that might allow a working class agenda to be followed.

The differences articulated between Milliband and Poulantzas touched off a heated debate, largely based on the relative autonomy each granted or denied to the state. Ollman, however, notes that:

The widespread debate among Marxists over the relative autonomy of the state usually goes on at cross purposes because the people 
involved do not sufficiently distinguish between these different Marxist interpretations of the state, and hence whether (under certain circumstances) the state is relatively autonomous from the ruling or capitalist class, or from economic requirements of capitalism, or from other alienated social relations, etc. As a matter of fact, there is a case to be made for relative autonomy within each of these perspectives on the state. What is important is to avoid the confusion that results from thinking there is only one debate when there are really several.

(Ollman, 1993, p. 92). Milliband viewed the state from the vantage point of the ruling economic class. Poulantzas viewed that same state from the vantage point of the socio-economic structure that encases political function. "As a result, Milliband is better able to account for the traditional role of the state in serving ruling class interests." (Ollman, 1993, p. 78). "Poulantzas has an easier time explaining the relative autonomy of the state, and why the capitalist state continues to serve the ruling class when the latter is not directly in control of state institutions.” (Ollman, 1993, p. 78).

Later, Poulantzas altered his theorization of the state (by altering his abstractions) to reflect the state as an arena for class action. (Poulantzas, 2001). Poulantzas relied heavily on Gramsci in formulating his later Marxist state, but Gramsci differed in ways that seem to seat him closer to Milliband with regard to state theorizations.

\section{3 $\quad$ Gramsci's Contribution}

Unlike Poulantzas or Milliband, Gramsci never developed a comprehensive theory of the state, but he made significant contributions to Marxist theorizations of the state which are relevant to this dissertation, and he helped explain the absence of Marxist revolution. Primarily, Gramsci developed the concept of hegemony, or rule by some level of consent, thereby theoretically allowing the influences of the societal masses to impact the state if consent was withdrawn. (Forgacs (ed.), 2000). This development is particularly relevant in this 
dissertation, because it explains the need for a devolution or shift in power. Gramsci's concept of hegemony underlies the conceptual development of flexible rescaling, because it explains why the state would need to shift power within the structure of the system. If viewed in terms of hegemony, flexible rescaling occurs as result of a threat of withdrawn consent. The state attempts to maintain or regain consent by shifting power to another scale- a scale at which potential opposition would be differently structured in a way that benefitted capital or a scale at which the composition or strength of opposition might differ in a way that made the opposition more manageable by the state and/or capital or in a way that allowed opposition to be overcome.

Gramsci's concept of hegemony attempted to explain why Marxist revolution had not occurred by the $20^{\text {th }}$ century. Consent had prevented a revolution. (Forgacs, ed., 2000). In the context of eminent domain, Gramsci's concept of hegemony will be used to explain why the $\underline{\text { Kelo }}$ decision focused so heavily on "public benefit" and why the doctrines of "public use" and “public benefit” have become cornerstones of American Eminent Domain. Briefly, for example, and as will be explained in more detail later, the United States Supreme Court handed down a decision commonly referred to as "Kelo" wherein capital attempted to gain consent to accumulation by dispossession by selling public benefit to those being dispossessed. ${ }^{1}$ Kelo v. City of New London. This form of consent gathering explains why successful eminent domain projects have surrounded public works projects or projects couched in public works, as will be explained in more detail later in discussing the new concept of flexible rescaling. (see generally, (Berman v. Parker, Hawaii Housing Authority v. Midkiff, and Poletown Neighborhood Council

\footnotetext{
${ }^{1}$ Kelo v. New London is an eminent domain case that was heard by the United States Supreme Court. The town of New London wanted to hand over its legal ability to seize private homes to a private entity, the New London Development Corp, in order to "develop" the area for Pfizer, which had a plant in the area. One homeowner, Susette Kelo, appealed her claim to the United States Supreme Court which ultimately ruled against her. Now Pfizer is pulling out of the deal following its merger with Wyeth.
} 


\section{v. City of Detroit).}

Gramsci recognized that to achieve consent the Marxist state does not always act entirely in the self-interest of the bourgeoisie. Rather Gramsci's state was capable of acting in the short term interest of the working class to the detriment of the short term interest of the bourgeoisie so long as ultimate benefit to the bourgeoisie could be maintained, thereby preventing revolution. In the high voltage transmission line case in Appalachia, the West Virginia Public Service Commission forced TrAIL to study an alternate route for the line which parallels an existing high voltage transmission line. TrAIL objected stating that the alternate route was outside the study area dictated by TrAIL and that it was an inferior route, but the State forced the study on the route regardless, thereby acting in the short term interest of citizens. (WV PSC Case No. 07-0508-E-CN). The alternate route was the one approved by the West Virginia Public Service Commission, thereby obtaining some level of public consent, at least by those who actively opposed the original route, who at that point essentially disappeared from the TrAIL opposition. This battle over electrical lines will be more thoroughly explored later, but it is introduced here to illustrate how Gramsci's theory of hegemony was exemplified when the ultimate route was approved. If the original route had been approved, then TrAil and its capital interest would have succeeded but consent would not have been obtained. But when the alternate route was ultimately approved, then the bourgeoisie interest in seeing the line built was still realized, despite the state acting in the short term interest of citizenry whose land would have been taken by the original but not the alternate route. Gramsci justified such actions based on a recognition that state action takes place against a complex backdrop of political, economic, and social relations. (Forgacs (ed.), 2000).

Gramsci examined generally how the state was able to subordinate the will of the 
masses to the interests of the elite. (Forgacs (ed.), 2000). He noted differences between domination by exercise of force and domination by ideology or consent. (Forgacs (ed.), 2000). These ideas form the bases of Gramsci's concept of hegemony. For Gramsci the concept of hegemony involved at least some level of consent to being ruled, in addition to some application of force and violence. The ruling class establishes hegemony at the point when it has gained the consent of the class being ruled to the violence being exerted by the state. This concept of hegemony is revisited below in discussing the TrAIL project in more detail and in the context of the examination and development of the concept of flexible rescaling. ${ }^{2}$

2 At the time of publication of this dissertation, TrAIL was in the permitting stages in West Virginia, having been approved in principle by the WV PSC in January of 2009. 


\section{Chapter 3}

\section{Uneven Development and the State}

In its simplest form, "uneven development" is the purposeful social and spatial differentiation of development between persons and places. (Smith, 1990, Ch. 4). Such purposeful differentiation means that both economic and social development is uneven over space and time. Smith links uneven development to the geographical expansion of the contradictions of capital. He sees both development and underdevelopment as connected processes necessary to capitalism. Underdevelopment is not just the failure of an area to develop; it is actively produced. (Frank, 1967). In other words, capital is agglomerated in one place in favour of another. (Smith, 1990). The need for continued expansion in capitalism results in either necessary geographic expansion, with attendant development and underdevelopment, or expansion by some other means, such as where places are redeveloped and resources are recaptured as a means on expansion. Either way the process of capitalism reinvents itself, and patterns of unevenness change over time as social and spatial development ebbs and flows.

Initially, some places are naturally better suited for development to occur, and, as a result, initial development occurs faster and with greater complexity in those areas. (Smith, 1990). The logical corollary is that areas that are not as well suited for development initially lag behind, and uneven development results. But these natural conditions that spark or suppress development fail to explain the purposeful and extreme level of differentiation eventually observable.

With the advent of transportation and advances in communication, the natural obstacles of some places, namely raw materials and distance or relative isolation, largely are overcome. So while the principle of natural advantage adequately explains initial uneven development, it fails to explain the continuation of uneven development or why, with 
technological advancements, underdeveloped places never manage to catch up.

The continuation of uneven development following the equalization of the playing field by transportation and communication results from the division created by capital of the means of production between classes. When the means of production are taken from workers, and reside only with capitalists, uneven development results. (Smith, 1990, Ch. 4). In essence, the capitalist process then actively creates pockets of development and underdevelopment necessary for capital accumulation to continue. The capitalist process creates a system where power and resources are purposefully concentrated in the hands of some while others are kept without access to or control over that power and those resources. This system forces those without the benefit of development to be and remain dependent on the opposing pockets of development.

Harvey recently added to Smith's theory of uneven geographical development by arguing for a dialectical and relational approach built upon four radically distinct recognized conditionalities. "The four conditionalities are:

1) The material embedding of capital accumulation processes in the web of socioecological life.

2) Accumulation by dispossession (a generalization of Marx's concept of 'primitive' or 'original' accumulation under which preexisting assets are assembled as labor powers, money, productive capacity or as commodities and put into circulation as capital).

3) The law-like character of capital accumulation in space and time.

4) Political, social, and 'class' struggles at a variety of geographical scales." (Harvey, 2006, p. 75). 
Harvey urges stressing the internal relations between these conditionalities. He advocates for a theory that "acknowledges the power and importance of certain processes that are specifiable independently of each other but which can and must be brought together into a dynamic field of interaction." (Harvey, 2006, p. 76). Essentially, here he advocates for a more dialectical and less formulaic approach to analyzing and explaining uneven development.

Harvey retains the spatial focus of uneven development. "The very term uneven geographical development is predicated upon some conception of what spatiality is all about." (Harvey, 2006, p. 77). He urges us, however, to continue to view spatiality as Lefebvre and Smith explained it, as "actively produced and as an active moment within the spatial process." (Harvey, 2006, p. 77).

The traditional examinations of the state's role in uneven development have been limited. These traditional examinations are dominated by three geographers (Brenner, Smith, and Harvey) whose work is discussed below. This dissertation seeks to illustrate that the valid connections made to date between the state and uneven development by those three geographers remain under-theorized, however, largely because none of the three have undertaken any significant analysis of the interconnections between active state spatial practices and capital accumulation processes.

Before further exploring the link between active state spatial practices and capital accumulation strategies and the resultant production of uneven development theorized by this dissertation, it is necessary to examine the work done on state spatial practices and capital accumulation strategies independent of one another and the existing work that links the state and uneven development. 


\subsection{Capital Accumulation Strategies}

Harvey has re-identified and named two distinct, but dialectically related, forms of capital accumulation, accumulation by dispossession and accumulation by expanded reproduction. Both forms have their genesis, according to Harvey, in collective imperialist practices between capitalists and the state, which practices are typically about exploiting the uneven geographical conditions under which capital accumulation occurs which take advantage of certain asymmetries. According to Harvey, such uneven geographic conditions arise as wealth and power become concentrated in certain places because of asymmetrical exchange relations. (Harvey, 2003).

Accumulation by expanded reproduction amounts to capital accumulation as we typically see it. It is production of goods and services. Harvey defined accumulation by dispossession as the "continuation and proliferation of accumulation practices that Marx had treated as 'primitive' and 'original' during the rise of capitalism." (Harvey, 2006, p. 43). Accumulation by dispossession amounts to robbery, sanctioned and assisted by the state's approval of the activities of capital. Harvey provides examples of this continuation of primitive or initial accumulation:

commodification and privatization of land and the forceful expulsion of peasant populations (as in Mexico and India in recent times); conversion of various forms of private property rights (common, collective, state, etc.) into exclusive property rights; suppression of rights to the commons; commodification of labor power and the suppression of alternative (indigenous) forms of production and consumption; colonial, neo-colonial, and imperialist processes of appropriation of assets (including natural resources); monetization of exchange and taxation, particularly of land; the slave trade (which continues particularly in the sex industry); and usury, the national debt, and most 
devastating of all, the use of the credit system as radical means of primitive accumulation.

(Harvey, 2006, p. 43). Important to our analyses here, Harvey recognizes that the "state, with its monopoly of violence and definition of legality, plays a crucial role in both backing and promoting these processes." (Harvey, 2006, p. 43). This dissertation attempts to fill the gap left by Harvey when he decided not to undertake an explanation of how the state plays such a crucial role.

Harvey's explanation of accumulation by dispossession is founded upon four essential elements. Those elements are privatization, financialization, the management and manipulation of crises, and state redistributions. (Harvey, 2006, pp. 44-50). Each element is discussed in turn below.

First, privatization is defined by Harvey as the "transfer of assets from the public and popular realms to the private and class-privileged domains." (Harvey, 2006, p. 45). Prior to Harvey's recent statements on privatization, the definition of privatization had been restricted to the transfer of productive public assets from the state to private companies. (Roy, 2001). Harvey's recent expansion of the concept of privatization within the context of accumulation by dispossession to include transfers to class-privileged domains is important to the analysis of this dissertation and particularly relevant to the expansion of the public use doctrine and the case study regarding eminent domain included herein.

Second, financialization, hallmarked by Harvey primarily as predatory lending and speculative investment, is also an element of accumulation by dispossession. In initially developing the concept of accumulation by dispossession as a spinoff of primitive accumulation used to avert capitalist crisis, Harvey stressed the importance of finance. His definition of the elements of accumulation by dispossession underscores that emphasis. (Harvey, 2006, p. 45). 
The third element of accumulation by dispossession, as outlined by Harvey entails the management and manipulation of crises where there is a deliberate redistribution of wealth that makes way for additional accumulation. Here the state enters Harvey's analysis as he notes that "[o]ne of the prime functions of state interventions and of international institutions is to orchestrate crises and devaluations in ways that permit accumulation by dispossession to occur without sparking a general collapse or popular revolt." (Harvey, 2006, p. 47). Harvey does not endeavor to reveal the state mechanism that acts behind such orchestration.

Finally, Harvey identifies state redistributions as the fourth element of accumulation by dispossession. Here he does scratch the surface of how the state intervenes in accumulation by dispossession noting that the state employs "redistributive policies" through privatization schemes and reduction of state expenditures that provide social support. (Harvey, 2006, p. 48).

Harvey asserts that he chose not to expand his theory of accumulation by dispossession to intranational situations because of the work on uneven development done by Smith. Therefore, to link accumulation by dispossession to intranational practices, some level of reconciliation and linkage with Smith's work on intranational uneven development will be required.

Before exploring further the link between accumulation by dispossession and accumulation by expanded reproduction and active state spatial practices, it is necessary to understand the dialectical relationship between the state and capital. That relationship between the state and capital is Harvey's "new imperialism," on which both forms of capital accumulation depend. It is the state sponsored geographic dynamics of capital accumulation that make the transition between accumulation by dispossession and accumulation by expanded reproduction 
possible.

This dissertation will examine that dialectical relationship between the state and capital and how it interplays with the two forms of accumulation identified by Harvey through active, deliberate spatial practices. Harvey notes that the institutional arrangements of the state set the stage for capital accumulation. The state acts as a territorial framework within which the process of capital accumulation operates. (Harvey, 2003, p. 89). Capital accumulation flourishes within a system of institutional structures of law, private property, contract, and security of money form. (Harvey, 2003, p. 89). However, how the state executes the function of establishing and maintaining an institutional structure of law, private property, contract, and security of money form remains under-theorized. An understanding of Harvey's accumulation strategies is paramount.

Harvey recognizes that political power is an always unstable mix of coercions, emulations, and, relying on Gramsci, the exercise of leadership through the development of consent. (Harvey, 2003, p. 42). Money, productive capacity, and military might are the engines that drive these power processes on an international scale. This dissertation will attempt to illustrate that on an intranational scale, the engines that drive the power processes are money, productive capacity, and regulatory power.

While Harvey leaves discussions of imperialism wed to interstate relations, imperialist practices are equally evident within states. Confinement of such intrastate processes to a general theory of uneven geographical development misses a quintessential opportunity to abstract intrastate practices in terms of the two forms of capital accumulation identified by Harvey. Also, intrastate imperialism provides a good venue for accumulation by dispossession, because intrastate regulation is often fundamentally linked to propertied interests. 


\section{2 $\quad$ State Spatial Practices}

An accurate and thorough understanding state spatial practices is essential to examining the state's role in uneven development. This dissertation will focus on two aspects of state spatial practices: Harvey's grid of spatial practices and the new concept of flexible rescaling. Harvey's grid of spatial practices is discussed and the concept of flexible rescaling is introduced below.

\subsubsection{Harvey's Grid of Spatial Practices}

In addition to analyzing the two forms of capital accumulation, Harvey also contributed to the proposed research through his development of a grid of spatial practices. The grid initially was used by Harvey to analyze the spatial practices of individuals, but in this dissertation it will be used to analyze state spatial practices. As used by Harvey, the grid examines how people's spatial practices impact their relations with space.

The grid examines how three different spatial practices work. Those three spatial practices are experienced or material spatial practices, perceived spatial practices, and spaces of representation or imagined spatial practices. First, experienced or material spatial practices are physical flows and transfers across space and time. Second, perceived spatial practices are representations of space or signs and significations that allow transfers to be understood. Third, imagined spatial practices or spaces of representation are mental inventions of new meanings for spatial practices. More specifically, the grid examines how these three conceptualizations of spatial practices impact how people see and use space.

The grid looks at how people see and use space in four different ways. These four ways space is used are accessibility and distanciation, appropriation of space, domination of space, and production of space. First, accessibility and distanciation is the measure of the 
degree to which friction of space has been overcome to accommodate social interaction. Here

distance is both a barrier to and a defense against social interaction. Second, appropriation of

space is how space is taken or assumed by individuals. Third, domination of space by

individuals or powerful groups is the legal or extra-legal means to control space. Last,

production of space is how new systems and representations are formed. (Harvey, 1989).

\begin{tabular}{|c|c|c|c|c|}
\hline & $\begin{array}{l}\text { Accessibility and } \\
\text { distanciation }\end{array}$ & $\begin{array}{l}\text { Appropriation and } \\
\text { use of space }\end{array}$ & $\begin{array}{l}\text { Domination and } \\
\text { control of space }\end{array}$ & Production of space \\
\hline $\begin{array}{l}\text { Material spatial } \\
\text { practices } \\
\text { (experience) }\end{array}$ & $\begin{array}{l}\text { flows of goods, } \\
\text { money, people } \\
\text { labour power, } \\
\text { information, etc.; } \\
\text { transport and } \\
\text { communications } \\
\text { systems; market and } \\
\text { urban hierarchies; } \\
\text { agglomeration }\end{array}$ & $\begin{array}{l}\text { land uses and built } \\
\text { environments; social } \\
\text { spaces and other } \\
\text { 'turf' designations; } \\
\text { social networks of } \\
\text { communication and } \\
\text { mutual aid }\end{array}$ & $\begin{array}{l}\text { private property in } \\
\text { land; state and } \\
\text { administrative } \\
\text { divisions of space; } \\
\text { exclusive } \\
\text { communities and } \\
\text { neighbourhoods; } \\
\text { exclusionary zoning } \\
\text { and other forms of } \\
\text { social control } \\
\text { (policing and } \\
\text { surveillance) }\end{array}$ & $\begin{array}{l}\text { production of } \\
\text { physical } \\
\text { infrastructures } \\
\text { (transport and } \\
\text { communications; } \\
\text { built environments; } \\
\text { land clearance, etc.); } \\
\text { territorial } \\
\text { organization of } \\
\text { social infrastructures } \\
\text { (formal and } \\
\text { informal) }\end{array}$ \\
\hline
\end{tabular}

\begin{tabular}{|c|c|c|c|c|}
\hline $\begin{array}{l}\text { Representations } \\
\text { of space } \\
\text { (perception) }\end{array}$ & $\begin{array}{l}\text { social, psychological } \\
\text { and physical } \\
\text { measures of distance; } \\
\text { map-making; } \\
\text { theories of the } \\
\text { 'friction of distance' } \\
\text { (principle of least } \\
\text { effort, social physics, } \\
\text { range of a good, } \\
\text { central place and } \\
\text { other forms of } \\
\text { location theory) }\end{array}$ & $\begin{array}{l}\text { personal space; } \\
\text { mental maps of } \\
\text { occupied space; } \\
\text { spatial hierarchies; } \\
\text { symbolic } \\
\text { representation of } \\
\text { spaces; spatial } \\
\text { 'discourses' }\end{array}$ & $\begin{array}{l}\text { forbidden spaces; } \\
\text { 'territorial } \\
\text { imperatives'; } \\
\text { community; regional } \\
\text { culture; nationalism; } \\
\text { geopolitics; } \\
\text { hierarchies }\end{array}$ & $\begin{array}{l}\text { new systems of } \\
\text { mapping, visual } \\
\text { representation, } \\
\text { communication, etc: } \\
\text { new artistic and } \\
\text { architectural } \\
\text { 'discourses'; } \\
\text { semiotics. }\end{array}$ \\
\hline $\begin{array}{l}\text { Spaces of } \\
\text { representation } \\
\text { (imagination) }\end{array}$ & $\begin{array}{l}\text { attraction/repulsion; } \\
\text { distance/desire; } \\
\text { access/denial; } \\
\text { transcendence } \\
\text { 'medium is the } \\
\text { message'. }\end{array}$ & $\begin{array}{l}\text { familiarity; } \\
\text { hearth and home; } \\
\text { open places; } \\
\text { places of popular } \\
\text { spectacle (streets, } \\
\text { squares, markets); } \\
\text { iconography and } \\
\text { graffiti; advertising }\end{array}$ & $\begin{array}{l}\text { unfamiliarity; } \\
\text { spaces of fear; } \\
\text { property and } \\
\text { possession; } \\
\text { monumentality and } \\
\text { constructed spaces } \\
\text { of ritual; symbolic } \\
\text { barriers and } \\
\text { symbolic capital; } \\
\text { construction of } \\
\text { 'tradition'; spaces of } \\
\text { repression }\end{array}$ & $\begin{array}{l}\text { utopian plans; } \\
\text { imaginary } \\
\text { landscapes; science } \\
\text { fiction ontologies } \\
\text { and space; artists' } \\
\text { sketches; mythologies } \\
\text { of space and place; } \\
\text { poetics of space } \\
\text { spaces of desire }\end{array}$ \\
\hline
\end{tabular}

Figure 1: Grid of Spatial Practices. (Source: Harvey, 1989). 
While to date the use of Harvey's grid has been specific to individual spatial practices, examining the grid shows that it can be applied to the spatial practices of the state in the context of uneven development. Harvey provides explanations and examples of how different classes of individuals construct their sense of territory and community differently in the American city. (Harvey, 1987). This dissertation will use the grid to provide explanations and examples for how the state uses space.

\subsubsection{Flexible Rescaling}

There has been significant research into rescaling. Both Smith and Brenner have contributed to the literature regarding rescaling. Smith discussed rescaling as the ability of the state to alter the power structure to concentrate power differently. (Smith, 2003). In Smith's research to date, this alteration of the power structure has been confined to physical rescaling where the structure of the state changes with the concentration of power, as happened with the creation of the EU. (Smith, 2003). Brenner has recognized rescaling as a state spatial practice by acknowledging that rescaling is an "active political action to facilitate, manage, mediate, and redirect processes of geo-economic restructuring." (Brenner, 2004, p. 61). But, like Smith, Brenner does not discuss rescaling outside the context of restructuring.

This dissertation will attempt to take the concept of rescaling beyond the boundaries of Smith and Brenner by explaining that the spatial practices of the state can be inherently flexible. The concept of flexible rescaling which will be introduced in this dissertation recognizes the ability of the state to rescale without formally restructuring. If this view of the state is adopted, then the state can be seen as capable of mobilizing scale as a spatial practice in order to benefit capitalism absent restructuring. The state could then respond to its need to manage power differently without formally restructuring. 
The problem with formal restructuring is that it might dissolve the state and recreate it, thereby creating certain political change and potential political instability. The state tries to avoid this political instability. This dissertation will argue that the ability to flexibly rescale is integral to the state's role in uneven development and to the avoidance of conflict. This proposed ability of the state to rescale without restructuring is an ability built into the framework of the state, for use to the benefit of the state and capital when needed. With flexible rescaling, the state has the ability to change the way it regulates without changing the formal fixed scales of government and without risking revolution.

Smith's more recent work on scale reflects a recognition of the "simultaneity of scales." (Smith, 2000). Smith describes that simultaneity as the interflow between bodily, global, and intervening scales where scales are embodied and reconstructed at the same time. Smith argues that this simultaneity of scale demonstrates the socially constructed nature of scales. (Smith, 2000). Smith recognizes scaling (and rescaling) as the product of economic, political, and social activities and relationships. (Smith, 2000). But, Smith never directly recognizes the component of flexibility built into the state's regulatory framework which allows for change without formal restructuring.

One of the overarching points which will be made in the dissertation is that the state is flexible, and that flexibility amounts to a spatial practice of the state, the impact of which goes largely unnoticed and unconsidered. The flexibility to devolve power between scales is inherent. No formal restructuring is required to transfer or devolve power. 


\section{Chapter 4}

\section{Geographic Theorizations to Date Regarding the State and Uneven Development}

Certain concepts already have been developed that significantly contribute to the current conceptualization of the state's role in uneven development. Those concepts act as the foundation for a more complete theorization of the state's role in uneven development. This dissertation intends to use those existing geographic theorizations regarding the state's role in uneven development, as well as to extend beyond their boundaries to make connections not before developed. "To begin with, . . . abstractions do not and cannot diverge completely from the abstractions of other thinkers . ... There has to be a lot of overlap. Otherwise, [one will] have constructed what philosophers call a 'private language,' and any communication between [one] and the rest of [the world] would be impossible." (Ollman, 1993, p. 27). Therefore, before exploring further how the interplay between state spatial practices and capital accumulation strategies impacts uneven development, it is first necessary to examine what geographers have already said about the state's role in uneven development.

Many geographers have addressed the functional and institutional roles of the state which contribute to theorizations of uneven geographic development. Only three, however, Neil Brenner, Neil Smith, and David Harvey, attempt a theorization of how those roles play out as the state's actual role in uneven geographic development. In fact, in addition to those three, the non-geographer Marxist social theorists discussed above, like Milliband and Poulantzas, have gone farther toward explaining the role of the state in uneven development than the majority of the remaining geographers.

\subsection{The Institutional and Functional Roles of the State}

A discussion of those geographers who have offered explanation of the institutional and functional roles of the state, generally, without meaningfully linking the role of 
the state to uneven geographical development, is required when examining the geographical literature on the state's role in managing uneven development. It is required, because such a linkage obviously follows, (Cox, 2004), regardless of the failure of those geographers to ultimately make such a linkage.

More than two decades ago, state theory moved from an instrumentalist conception toward a recognition of the complexity and specificity of the state and its distinctive organizational nature as a set of apparatuses. (Blomley, 1988). Following such a recognition, the state was no longer regarded by most merely in an instrumental fashion or simply reduced to a functional expression of capitalist imperatives. Recognition was given by many state theorists that the state also has the qualities of an autonomous actor. (Blomley, 1988).

Mann identified the power of the state, which arguably underlies the resultant uneven development within the state, as twofold. (Mann, 2003). Per Mann, these two state powers are despotic and infrastructural. Despotic powers are defined by Mann as the range of actions the elite can take without institutional negotiations with civil society groups. These powers are also called the "autonomy of power" of the state elsewhere in the geographic literature. They are the "power over civil society." By contrast, infrastructural powers are articulated by Mann as the capacity of the state to penetrate civil society and implement political decisions. According to Mann these are the more common and concerning powers like the powers to tax income and wealth, to collect information on the citizenry, to enforce rules and regulations instituted by the state, to regulate the economy, and to directly provide for the subsistence of at least some citizens (Mann argues most) in the form of state employment, pensions, and family allowances. (Mann, 2003). This power is the power of the state to penetrate and centrally coordinate the activities of civil society 
According to Mann, infrastructural power is strong in relation to individuals and weak in relation to groups. Examples of infrastructural power development given by Mann (without any explanation of how those powers are developed) are the central division of labor between entities centrally coordinated, the storage power over information and the ability to codify laws, the control of coinage and weights and measures and the guarantee of value, and the provision of rapid communication and transportation, what Harvey would term structured coherence, to society. (Mann, 2003). However, Mann's attempts to reduce the possible incarnation of the state to four ideal types fails, particularly where imperial states are defined by Mann as possessing high despotic and low infrastructural powers. Such a restriction of power in imperial states seemingly is an incorrect denial of significant infrastructural power to imperial states.

Mann identifies the primary functions of the state as all falling under the umbrella of rulemaking. They are the persistent actions of maintaining order, namely protecting the propertied classes from the propertyless, military defense in the form of collective action or military aggression in the form of action to the benefit of specific interests, the provision of what Harvey would call structured coherence, and economic redistribution, including international redistribution through market regulation. Mann suggests that the power to undertake these functions arises primarily from the territorial centrality of the state. (Mann, 2003). Mann is not the only scholar to discuss the state's actions in detail, however.

Silvern discusses state regulation in his analysis of American Indian Treaty rights juxtaposed against the doctrines of state centrism and equal footing. (Silvern, 2002). In examining these rights and this regulation, Silvern exposes, consistent with Delaney's analysis, that despite the Supreme Court saying that both states and the federal government may regulate 
use of state space, even in the face of treaties arguably silent on the issue, "to the present time there never has been either legal analysis or citation of a non-dictum [or non-binding] authority in any decision of the Supreme Court of the Land in support of its decisions holding that state police power may be employed to limit or modify the exercise of rights." (Silvern, 2002, p. 51).

The state furthers and maintains an impression of its own position both as a legitimate and as an autonomous actor within the space-economy and, secondary to this, as an efficacious social agent. (Blomley, 1988). Delaney argues that the legal system is used to these ends, to "enlist the power of the state to validate some versions in preference to other competing versions." (Delaney, 2001, p. 490). By this description of law, we understand law to be one tool (if not the primary tool) employed by the state to manage uneven development, regardless of scale.

Given the state's requirement of legitimacy, however, the state must "function and appear as an impartial arena, as a site of justice, it must also serve to constrain the power and ambitions of national and subnational governments, and thus can serve to recognize and even protect" marginalized groups in order to retain requisite legitimacy. (Silvern, 2002, p. 35). Law, therefore, becomes a site of domination and resistance, colonization and decolonization, (Silvern, 2002, p. 35) . . . a site for uneven development. Despite these recognitions of the legitimation required to maintain the state's power and the general role of the law in securing legitimation, how the law mediates to provide such legitimation to the state, as a system, has never been theorized. Instead, scholars to date have recognized that law provides requisite legitimation, but they have never undertaken to discuss how, except for the basic recognition that legitimation results from the appearance of justice created by the law. 


\subsection{Brenner, Smith, and Harvey on the State and Uneven Development}

In critically discussing the state's role in managing uneven development, it is instructive to examine the state's role in two regards: first, with regard to the state's role in managing classic uneven regional development as theorized by Neil Brenner and Neil Smith, and to some extent by Harvey, and, second, with regard to the state's role in managing accumulation strategies. While Harvey has restricted his analysis of accumulation strategies and accumulation by dispossession to international imperialism, his analysis of capital accumulation strategies can be expanded to intranational imperialism where the state's role has yet to be sufficiently theorized.

Brenner, Smith, and Harvey all have made significant contributions to the geographic literature by taking us beyond the traditional institutional and functional roles of the state to examine some aspects of the linkages between the state and uneven development. Briefly stated, Brenner posits that the state's role in uneven development is twofold: first, the state acts as a form of territorialization for capital and, second, the state acts as an institutional mediator of uneven geographical development on differential, overlapping spatial scales. (Brenner, 1998). Finding scale to be absolutely central to the processes and politics of uneven geographical development, Smith generally posits that the state's role in uneven development is to form the territorial container for social action, thus defining territorial scale and creating a foundation where uneven geographical development can occur. (Smith, 1990). Both of these geographers obviously build primarily on the Marxist state theories of Poulantzas, Milliband, and Gramsci. Lastly, Harvey generally defines the state as a power arising from, but placed above, society to moderate conflict between the classes which becomes the locus of power by which class domination through law, taxation, and coercion can occur. (Harvey, 1978). From this 
definition he develops the state's role in varying forms of capital accumulation resulting in uneven development as the role to hold a monopoly of violence and a definitional power over legality, thereby playing a crucial role in backing and promoting the processes of accumulation. (Harvey, 2003).

\subsubsection{Brenner on the State's Role in Uneven Development}

Brenner's earlier work connects the state's spatial attributes of "spatial tactics" and "spatial targets" to uneven development by noting that the state tolerates and even encourages uneven development as cities and regions participate in competition over capital development and accumulation strategies (Brenner, 1997a). Brenner has written at length regarding the spatiality of the state, with questionable success. However, only Brenner's earlier connections to uneven development are addressed herein. This dissertation seeks to further Brenner's earlier work and to correct his later misadventures into state spatiality.

Brenner sees the key roles of the state as acting as a form of territorialization for capital and acting as an institutional mediator of uneven geographical development on differential, overlapping spatial scales. (Brenner, 1998). For Brenner forms of territorialization of capital are always scaled. These scales circumscribe the social relations of capital within determinate, but highly contested, geographical boundaries and "hierarchize" them (the social relations) within relatively structured, although uneven and asymmetrical, patterns of sociospatial interdependence. (Brenner, 1998). Loosely theorized, state scaling contributes to uneven geographical development. Brenner develops this theory by relying on and extending LeFebvre. According to Brenner (1997b), who argues that the state scales to manage uneven development,

[t]erritorial states are confronted with new regulatory problems as their 'internal' spaces are continuously remolded through new 
patterns of industrialization, urbanization, regional development, underdevelopment, and socio-spatial polarization of different geographical scales. To regulate these new mosaics of socially produced geographical unevenness, the territorial state deploys a wide range of geographically specific policies oriented toward different cities, industrial districts, regions, growth poles, peripheries, 'underdeveloped' zones, rural areas, and so forth. In each case, Lefebvre argues, the state strives to construct 'a hierarchical ensemble of places, functions and institutions,' a task that at once entails biological reproduction, the reproduction of the labor force, the reproduction of the means of production, and the reproduction of the social relations of production and domination.

Brenner notes that LeFebvre argues that the state mode of production must be understood as both a form of territorialization for capital and also as the most important institutional mediator of capital's uneven geographical development on multiple intertwined scales, a traditionally Marxist view of the state. (Brenner, 1998). The state's delicate equilibrium for capital is then primarily based on the state's ability to command and control scale within its territorial space. (Brenner, 1998). Brenner identifies that the state uses space or scale as its privileged instrument to impact the relations between individuals, groups, class fractions, and classes. (Brenner, 1998). But how these scales are managed remains a mystery in Brenner's writings. What we do know from Brenner is that "[t]he contours of this uneven geography are not inscribed permanently onto the institutional landscapes of capitalism, but are reworked continually through capital's restless development dynamic and through successive political strategies to subject it to some measure of regulatory control," arguably an allusion to flexibility, although it remains more likely that Brenner was referring to a more classical restructuring when he referenced such a "reworking." (Brenner, 2004, p. 13-14).

Brenner acknowledges that uneven geographical development is, therefore, associated with new profit-making opportunities for capital and also with potentially destabilizing, disruptive effects that erode the socio-territorial preconditions for sustainable 
capital accumulation. (Brenner, 2004). Capitalist expansion and development can be dangerous even for capitalism because of its uneven formulations. While capitalist strategies of deterritorialization can succeed in circumventing some constraints imposed by national boundaries, they do not translate into true hyper mobility and placelessness and therefore are unsuccessful at alleviating the perils of uneven geographical development. (Brenner, 2004, p. 59).

\subsubsection{Smith on the State's Role in Uneven Development}

Smith has long focused on scale and uneven geographical development, linking the two through the state. He notes that "the demarcation of scale should be seen as absolutely central to the processes and politics of uneven geographical development." (Smith, 2003). Because the state forms the territorial container for social action, thus defining territorial scale, it creates a foundation where uneven geographical development can occur. When scalar divisions within the state are manifested, uneven geographical development is manifested. (Smith, 2003).

In his seminal text, Uneven Development, Smith explained the artificial, social construction of nature. While Smith's book falls short of conceptualizing how the state accomplishes this construction, he makes the fact that the state has a role in such construction clear. (Smith, 1990). A decade later, legal geographer David Delaney developed a hypothesis that the state's social construction of nature occurred by force of law. (Delaney, 2001). Delaney also notes that law is enforced by the organized violence of the centralized state, thereby extended Mann's theorization that territorial centrality of the state underlies state power, (Mann, 2003), and expounding slightly on Smith's linkage of the state and uneven development. (Delaney, 2001).

Smith does dismiss any argument of randomness of geographic unevenness. 
(Smith, 1990). Smith argues, instead, that uneven geographic development is the result of tensions created by the drive of capitalism to continually accumulate. More specifically, Smith identifies a tension between the tendency of capitalists to attempt to equalize investment across space (the tendency to replicate positive accumulation strategies) and the need for capitalists to diversify and expand at uneven and unpredictable paces (the result of competition and attempted differentiation between capitalists), resulting in an exploitation of space to allow for accumulation. (Smith, 1990). Capitalists attempt to seek out territorially unique advantages, and attempts at technological innovation also result in uneven geographic patterns. (Smith, 1990).

The functions of the state, according to Smith, with regard to controlling and managing uneven development, are twofold. The state arbitrates in favor of the ruling class, and the state divides people for public purposes by their common place of residence. (Smith, 1990). This division creates nationalism and localism. As a result, the state plays a crucial part in identity formation. (Smith, 1990). This observation by Smith allows us to meaningfully link issues of identity, both internal and external, to the state's actions. Appalachian identity formation illustrates this concept, with the state sponsored Appalachian Regional Commission continuing to form and impact Appalachian identity through its actions and initiatives.

Because Smith sees space as a commodity, the state's role in establishing territoriality is fundamental to the commodification of space. Smith opines that spatial properties are part of the use value of a commodity. If we see them as such, then each time the state impacts spatiality it impacts commodity value. Similarly, the spatial integration that takes place is fostered by the state. Capitalism's need to link commodities production through exchange is obviously heavily state regulated. The resultant progressive integration and transformation of absolute spaces into relative space identified by Smith is then managed by the state. The point of 
departure here is to explain how and why the state accomplishes these goals.

Smith's conception of the principle of natural advantage (discussed previously) may also be impacted directly by state action. Economic development initiatives and state financing impact the potential for uneven development and the potential to transcend it, thus underscoring the importance that would later be placed by Harvey on finance.

As stated, Smith recognizes that three primary state scales emerge. For him the scales are not fixed; they continue to be shaped by capitalist development. But the internal differentiation between the scales is fixed according to Smith. Once again, the scales he identifies are urban, nation-state, and global. Urban space is used as an absolute space of production. Production is centralized here and determines urban development. Smith postulates that urban space should be viewed as the expansion of the geographic sphere of "abstract labor." Labor first expands within urban space and eventually beyond it and then internally differentiates. (Smith, 1990). The nation-state scale is politically determined by a series of historical deals, compromises, and wars by or on behalf of the state. (Smith, 1990). Capitalism is then forced to act within or move beyond the confines of this state established scale. Smith notes that the nation-state scale is rigid and not capable of fluid expansion. It has both centralization and differentiation on a regional level which leads to rising and declining regions. The regions are the product of a differentiated nation state. The global scale is defined by Smith as the world market. (Smith, 1990). It universalizes wage labor and attempts to equalize. Its definition is also political, despite its lack of a unified state body. It is responsible for the production of class relations. Capital attempts to convert these spaces into places of production and accumulation as well as a location for consumption, but frequently, according to Smith, capital is unable to do so because of the inherent difficulties in attempting to make global spaces 
places of consumption while maintaining the underdevelopment that results in accumulation on a grand scale. At all three scales the state impacts uneven development and capitalism because of its roles in defining and redefining spatial and scalar state properties.

\subsubsection{Harvey on the State's Role in Accumulation Strategies and Uneven Development}

Before the New Imperialism (Harvey, 2003) was written, and contemporaneous with the proliferation of state theory, Harvey analyzed the Marxian theory of the state. This analysis appears to be Harvey's first implicit connection between the state and uneven geographical development. Harvey defined the Marxian state as a power arising from, but placed above, society to moderate conflict between the classes which becomes the locus of power by which class domination through law, taxation, and coercion can occur. (Harvey, 1978). Such class domination is the heart of uneven geographic development, and the power of the state articulated by Harvey to do so links the two.

In the 1980's Harvey expanded on Marx's identification of the propensity of global capitalism to attempt to "annihilate space by time." Harvey further theorized the contemporaneous orientation of capital to geographically expand and temporally accelerate. (Harvey, 1985, 1986, 1987, and 1989; recognized by Brenner, 2004). Harvey premised the ability to overcome space on the ability of capital to produce space, a process in which the state becomes intimately involved. (Harvey, 1985). Based on these assumptions, Harvey identifies the "spatial fix" and, even prior to Brenner, recognizes the propensity of capital to attempt continual restructuring as a result. (Harvey, 1985).

Harvey had earlier recognized the still persistent need for the state to appear independent and autonomous by defining an "illusory common interest" to foster consent, (Harvey, 1978) a theory more fully developed later by the New Imperialism. The key function 
of the state, in this regard, is to organize and guarantee certain benefits for labor which are not immediately beneficial to capital, but which ultimately will allow capital to further subordinate and dominate. Such benefits are guaranteed in exchange for allegiance by the subordinate classes. Harvey opines that international imperialism can be used to guarantee these benefits while gaining intranational allegiance. (Harvey, 1978). While he never postulates that intranational imperial practices may also be used to gain allegiance, such a theoretical extension is logical.

Harvey identified four basic functions which must be fulfilled by the state to support a capitalist system: creation of juridical individuals, creation and maintenance of a system of private property rights, determination of standard value, and creation of reciprocal dependence in exchange. He postulated that the performance of these functions would help to control the conflict between capital and labor, (Harvey, 1978) thereby allowing uneven development to persist.

Later, in the New Imperialism, in discussing the state's role in accumulation by dispossession, Harvey notes that the state, which holds a monopoly of violence and holds definitional power over legality, plays a crucial role in backing and promoting the processes of accumulation of dispossession. This role of the state is evident both as those processes are articulated by Marx to be the primitive accumulation processes of:

the commodification and privatization of land and the forceful expulsion of peasant populations; the conversion of various forms of property rights (common, collective, state, etc.) into exclusive private property rights; the suppression of rights to the commons; the commodification of labor power and the suppression of alternative (indigenous) forms of production and consumption; colonial, neo-colonial, and imperial processes of appropriation of assets (including natural resources); the monetization of exchange and taxation, particularly of land; the slave trade; and usury, the national debt, and ultimately the credit system. . . 
and as those processes are articulated additionally by Harvey. (Harvey, 2003, p. 145). Harvey contends that Marx's sketch of processes of primitive accumulation remains viable, but he finds the processes of manipulating the credit system and finance capital to play an even larger role in the continuing process of accumulation by dispossession than in the process of original primitive accumulation. Harvey identifies new processes as well, such as the commodification of cultural forms, histories, and intellectual creativities as well as usurpation of intellectual property rights and biopiracy. (Harvey, 2003). In addition, the creation of private property rights and use of state power to create and enforce those rights also can account for accumulation by dispossession.

The reason state intervention is so important in the process of accumulation by dispossession is that the state's assistance is required to orchestrate a devaluation of assets or labor in such a way as to permit accumulation by dispossession to occur while preventing a general economic collapse from happening. The state is also needed to create the essential link between accumulation by dispossession and accumulation by expanded reproduction. The state coordinates both processes to the benefit of the same capital powers. 


\section{Chapter 5}

\section{Ollman’s Dialectical Method}

The dialectical method will be used in this dissertation to make the essential connections between state spatial practices and capital accumulation which hopefully will illuminate the state's role in uneven development. The dialectical method places emphasis on process, internal relations, and contradictions. The method approaches systems as if those systems are in a constant state of change and flux. Problems with how we have historically studied the world are compounded by an approach that privileges whatever makes things appear static and independent over their more dynamic and systemic qualities. (Ollman, 1993, p. 10). In this regard, state space has been privileged over state spatial practices. The dialectical method restructures our thinking about reality by replacing our common sense notions of things as having a history and external connections with other things with the concepts of process and relation, the focus being on internal relations. (Ollman, 1993, p. 10). "Dialectics avoids the more mechanistic and reductionist versions of this problem and permits the issue to be approached theoretically in an open and fluid way." (Harvey, 2006, p. 76). The method has a relational ontology. (Merrifield, 1993).

In its essential form, the dialectical method involves employing a process called abstraction to move beyond appearances and understand the important relationships and connections between things. "Dialectics, and in particular that version of it which stresses internal relations, is perpetually negotiating the relation between the particular and the universal, between the abstract and the concrete." (Harvey, 2006, p. 76).

"[D]ialectical research begins with the whole, the system, or as much of it as one understands, and then proceeds to an examination of the part to see where it fits and how it 
functions, leading to a fuller understanding of the whole from which one has begun." (Ollman, 1993, p. 12). This method starts with the real concrete, defined as the world as it presents itself to us, and proceeds through abstraction or the intellectual activity of breaking the whole down into manageable mental units we can use to think about and understand the whole, through the thought concrete, which Marx defines as the reconstituted whole which then can be understood as a new whole. Every piece gets pulled from the whole, examined, and temporarily perceived as standing apart. (Ollman, 1993, p. 24).

Ollman provides a clear and useful example for understanding the process of abstraction. He notes:

In listening to a concert, for example, we often concentrate on a single instrument or recurring theme and then redirect our attention elsewhere. Each time this occurs, the whole music alters, new patterns emerge, each sound takes on a different value, etc. How we understand the music is largely determined by how we abstract it.

(Ollman, 1993, p. 25).

Dialectical research traces four types of relations. Dialectical research also uses three modes of abstraction to examine the elements of a given whole. Both the relations and the process of abstraction require further explanation.

\section{$\underline{5.1} \quad \underline{\text { Four Dialectical Relations }}$}

A dialectical relation is essentially a way of examining how some element of the whole relates to the whole or to other elements of the whole. The dialectical method identifies four different dialectical relations. (Ollman, 1993, p. 13). Those four dialectical relations are:

1. Identity/difference;

2. Interpenetration of opposites;

3. Quantity/quality; and 


\section{Contradiction.}

Each dialectical relation is explained briefly in succession below.

\subsubsection{Identity/Difference}

The first dialectical relation, identity/difference, is what Ollman terms the "perspectival element." (Ollman, 1993, p. 14). It recognizes that things appear differently depending on the perspective of the viewer. The identity of something is different depending on who sees it. In this respect, Ollman notes that Marx privileged the perspective of the worker. (Ollman, 1993, p. 14). Identity is essential to the forthcoming discussion of the extension aspect of abstraction. In embodies the sameness and difference of parts being analyzed, often with at least some portion of that sameness and difference existing simultaneously.

When "viewing parts as necessary aspects of each other, they become identical in expressing the same extended whole." We must first view abstracted parts as identical even before they have been abstracted from the whole. Examining them as identical aspects before they are abstracted from the whole ensures their unity. "Identity precedes difference." (Ollman, 1993, p. 43). Differences, though, when ultimately found do not destroy the identical nature of the parts. They do not create a problematic contradiction, they only allow us to better understand the true nature of the whole from which they have been abstracted. "Hence, the coexistence of identity and difference." (Ollman, 1993, p. 43).

\subsubsection{Interpenetration of Opposites}

The second dialectical relation, the interpenetration of opposites, refers to the situation of things in place and time. The relation recognizes that "nothing- no event, institution, person, or process- is simply and solely what it seems to be at a particular place and time." (Ollman, 1993, p. 14). Rather, if viewed under different conditions, the same thing may appear 
or actually be different than it seemed. This relation urges us to examine where and how change has already occurred and under what still-developing conditions new changes are likely to occur as a means of both gauging the complexity of the part [here the conceptual element of the state] and of determining its dependence on the evolution of the system.

\subsubsection{Quantity/Quality}

The third dialectical relation, quantity/quality, refers to change over time. This relation brings into single focus the before and after aspects of development. "Initially, movement within any process takes the form of quantitative change. One or more of its aspects . . . increases or decreases in size or number. Then, at a certain point . . a qualitative transformation takes place indicated by a change in its appearance or function." (Ollman, 1993, p. 15). Ollman notes that at this point of transformation in both quantity and quality what you are examining "has become something else while, in terms of its main constituting relationships, remaining essentially the same." (Ollman, 1993, p. 15).

Quantity/quality are important to the examination of both capital accumulation strategies and flexible rescaling. Quantity/quality is a historical movement whereby one or more aspects of what something is change in quantity. The aspects get larger or smaller and increase or decrease in number until the aspect attains "critical mass" and a qualitative transformation occurs. (Ollman, 1993, p. 49). In essence, once one aspect of a process or relation gets big enough or small enough, it changes the appearance and composition of the process or relation from which it was abstracted, and a qualitative change in what the process or relation is can be seen.

\subsubsection{Contradiction}

The fourth, and final, dialectical relation, contradiction, is the most important of 
the four relations. Contradiction can be understood as the incompatible development of different component parts which are at the same time dependent on one another. Ollman notes that dialectics "attribute[s] the main responsibility for all change to the inner contradictions of the system or systems in which [change] occurs." (Ollman, 1993, p. 17). Contradiction, then, focuses research on the internal contradictions within a given process, and dialectics focuses on internal relations. Contradiction includes both elements of historical movement and elements of organic movement. (Ollman, 1993, p. 50).

Contradiction encompasses five different "movements." Those five movements are mutual support, mutual undermining, eminent unfolding, change in overall form through interaction, and resolution. (Ollman, 1993, p. 51-52). Ollman contends that the first two movements are the most important, because each places a constant pulling in the opposite direction. "The uneasy equilibrium that results lasts until one or the other of these movements predominates." (Ollman, 1993, p. 51). These two movements are at the heart of both the transition between capital accumulation strategies and flexible rescaling.

The third movement, eminent unfolding, reflects a sharpening or intensifying of the first two movements, not necessarily to the same degree. The growth of the system as a whole leads to the growth of these contradictions as well. The contradictions become more obvious and stark as they growth within the system, and they become the elements most observable at this point in the movements.

The fourth movement results from the powerful growth of the third. This fourth movement is when change in the overall form occurs as the first two movements play themselves out. Ollman notes this movement can occur when the systemic interactions are the same but the entire contradiction gets metamorphosized. The fifth and final movement then occurs "in its 
resolution when one side overwhelms what has hitherto been holding in check, transforming both itself and all its relationships in the process." (Ollman, 1993, p. 52).

Ollman labels the way dialectics deals with change as the "double movement (organic and historical) of the capitalist mode of production." Recall that quantity and quality was referred to above as an historical movement, and contradiction was referred to above as having elements of both organic and historical movements. Ollman breaks that organic and historical double movement down into a number of sub-movements, some of which are synonymous with the four dialectical relations discussed above. His sub-movements include quantity/quality (discussed above), metamorphosis, and contradiction (discussed above), which he contends are the three most important, plus mediation, interpenetration of opposites (also discussed above), negation of negation, precondition and result, and unity and separation. (Ollman, 1993, p. 48).

Because Ollman contends that metamorphosis is one of the most important submovements of the double movement, it is important to understand that sub-movement as well. Metamorphosis examines organic movements of interaction within a system "in which qualities (occasionally appearances, but usually functions) of one part get transferred to other parts so that the latter can be referred to as forms of the former." (Ollman, 1993, p. 49). In metamorphosis, "a process is abstracted that is large enough to include both what is changing and what it is changing into," thereby implicating the process of abstraction of extension. (Ollman, 1993, p. 49).

In this dissertation, both capital accumulation strategies and state spatial practices each will be analyzed in terms of the dialectical relations, movements, and submovements identified and discussed above. This analysis will be performed through use of the modes of 
abstraction explained below as a means of better theorizing the state's role in uneven development and making connections between state spatial practices and uneven development. While these analyses will be perceptible, so as to avoid too positivist of a presentation, their inclusion will not be explicit.

\section{2 $\quad$ Three Modes of Abstraction}

A mode of abstraction is actually how you go about examining a particular concept. It differs from a dialectical relation in that instead of being the way a component part relates to others or the whole, a mode of abstraction involves how we figure out the way component parts relate to one another or the whole. Ollman notes that the process of abstraction actually comprises these three "modes of abstraction" or "aspects of abstraction." Those modes or aspects are:

1. Extension;

2. Level of generality; and

3. Vantage point.

(Ollman, 1993). Each mode of abstraction is explained in succession following a discussion of the process of abstraction generally.

In the process of abstraction Marx allows the researcher to break down the whole into mental units with which we think about it as a means of reconstituting that whole in a way that can be understood. (Ollman, 1993, 24). "In one sense, the role Marx gives to abstraction is simple recognition ... that all thinking about reality begins by breaking it down into manageable parts." (Ollman, 1993, p. 24). Through abstraction "a piece [is] pulled from or taken out of the whole and is temporarily perceived as standing apart." (Ollman, 1993, p. 24). "In 'abstraction' we have simply separated out, focused, and put emphasis on certain common features of these 
other processes." (Ollman, 1993, p. 25-6). Therefore, this dissertation separates the concepts of capital accumulation strategies and state spatial practices out from the concept of uneven development. This separation is being made, because it is thought that dialectical examination and the resulting understanding of capital accumulation strategies and state spatial practices will allow what Ollman identified here as their "certain common features," to foster a new understanding of the state's role in uneven development.

\subsubsection{Extension}

The first mode of abstraction, extension, deals with the spatial and temporal framework placed around the part abstracted. (Ollman, 1993, p. 39). While abstracting boundaries and limits in time, extension, like abstraction generally takes us from the concrete whole into abstracted parts and back to a mental recreation of the whole. It breaks the whole into pieces and then puts the pieces back together again. In doing so, abstraction of extension focuses on the qualities of identity and difference.

In this dissertation extension has already been employed to parse out two conceptual elements for study. Once such an abstraction is made, Ollman reminds us that Marx terms the abstracted elements "form," which Ollman notes is "Marx's chief way of telling us that he has found an identity in difference. [Things are at the same time different and part of the same whole.]" (Ollman, 1993, p. 43). In this dissertation an identity in difference has been found between state spatial practices and capital accumulation strategies, such that each can be treated as a form, both separately (recognizing their differences from one another) and wholly (recognizing that they are constituent parts of the uneven development of the state at the same time). 


\subsubsection{Level of Generality}

The second mode of abstraction, level of generality, refers to the process of extracting the general and specific characteristics from parts of the whole. Then the similarities and differences between specific and general characteristics are noted. Level of generality "is a move from a more specific understanding ... that brings into focus the whole network of equally specific qualities in which it functions to a more general understanding ... that brings into focus the equally general state of those conditions in which it occurs." (Ollman, 1993, p. 54).

Marx subdivides the world into seven major levels of generality. Marx organizes everything according to one of these seven levels. The levels are what is:

1. Unique to a person and situation;

2. General to a person and situation;

3. Capitalist;

4. Class Society;

5. Human Society;

6. The animal world; and

7. Qualities as a material part of nature.

Level one, what is unique to a person and situation is exemplified by proper names and addresses. Here whatever makes someone unique is brought into focus for as long as it lasts as a unique quality, then the transformation to level two, where generalities begin, takes place. At level two, abstracted into focus are the qualities that make us speak of an individual or situation in terms of classes, for Marx "as an engineer or in terms of some other occupation that has emerged in modern capitalism." (Ollman, 1993, p. 55). Bringing these more general qualities into focus then focuses us on what is at its most basic common among the individuals or 
situations examined at level one.

Level three is confined to capitalism. "[E]verything that is peculiar to people, their activity, and products due to their appearance and functioning in capitalist society is brought into focus." (Ollman, 1993, p. 55). This level allows Marx to look at typical works and beyond individuals and occupations. Level three broadens not only characteristics but time. It includes everyone that has taken part in the capitalist system over the history of capitalism. Of course debate remains as to when a capitalist system emerged. (See Generally, Dunaway, 1996).

Levels four, five, and six continue to progress through the levels of generality of class society, human society, and the animal world. They occur as the middle of Marx's continuum from specific to general. Level four focuses on the period of history where society can still be divided into classes based on their division of labor. Level five brings into focus qualities of people that result from the human condition as a common denominator. Level six broadens the generality even further to remove society from the equation, replacing it with a focus on the characteristics of "life functions, instincts, and energies" that are not common to just the human population, but which extend outward into the living world more generally. (Ollman, 1993, p. 56). Level seven is the most general of the levels of extension which focuses on even more general characteristics of being such as weight and extension.

[E]ach level, beginning with seven, establishes a range of possibilities for what can occur on the more specific levels that follow." (Ollman, 1993, p. 65). The significance of level of generality is found in the realization that "all the problems from which we suffer and everything that goes into solving them or keeping them from being solved is made up of qualities that can only be brought into focus on one or another of these different levels of generality." (Ollman, 1993, pp. 56-7). Therefore, "it is essential, in order to understand any particular 
problem, to abstract a level of generality that brings the characteristics chiefly responsible for this problem into focus." (Ollman, 1993, p. 57). We need to look at different levels of specificity to make valid determinations about anything we are examining. We must place any relation we intend to examine at the proper level of generality for its examination to be accurate, but there are movements that can be found or recognized regardless of the level of generality chosen. These movements are referred to as "laws of the dialectic." Three of the four laws of the dialectic have already been discussed: interpenetration of opposites, quantity/quality, and contradiction.

The fourth law of the dialectic is negation of negation. Negation of negation is also one of the dialectical movements within the historical and organic double movement Ollman identifies. (Ollman, 1993, p. 48). Negation of negation has not yet been discussed. It occurs when "the most recent phase in a development that has gone through at least three phases will display important similarities with what existed in the phase before last." (Ollman, 1993, p. 64). "[T]he laws of the dialectic do not in themselves explain, or prove, or predict anything, or cause anything to happen. Rather, they are ways of organizing the most common forms of change and interaction that exist on any level of generality for purposes of study and intervention into the world of which they are part." (Ollman, 1993, p. 65).

Consistent with Ollman's directives with regard to level of generality, geographers Cox and Mair have recognized that, "[d]iscarding more abstract concepts seems [] to be at least as dangerous as any tendency to work at too high a level of abstraction." (Cox and Mair, 1989, p. 125). While they have stated their preference to construct a network of concepts that refers to various aspects of the local, their urgings are relevant at any scale and are relevant to the level of generality mode of abstraction as a whole. (Cox and Mair, 1989). While they noted the 
significance of conceptualizing locality in terms of hierarchical levels of abstraction, the same strategy can be employed regardless of scale. This strategy is integral to, if not synonymous with, the level of generality mode of abstraction.

\subsubsection{Vantage Point}

The third mode of abstraction, vantage point, is essentially the "place from which to view the elements of any particular relation and, given its then extension, from which to reconstruct the larger system of which this relation belongs." (Ollman, 1993, p. 68). Vantage point recognizes that things are different depending on perspective. Simply put, vantage point recognizes that where and how close you are looking at something makes a definite difference in what you see. Dialectics "takes change as the given and treats apparent stability as that which needs to be explained and [] provides the specialized concepts and frameworks to explain it." (Ollman, 1993, p. 3).

Vantage point may be the mode of abstraction that explains the differing Marxist theories of the state discussed earlier that have evolved over time. Apparent contradictions in Marx's theory of the state may be resolved by recognizing their different, or even diametrical, vantage points. (Ollman, 1993, p. 67-8). Vantage point results in the creation of a "perspective that colors everything which falls into it, establishing order, hierarchy, and priorities, distributing values, meanings, and degrees of relevance, and asserting a distinctive coherence between the parts." (Ollman, 1993, p. 67-8).

Because of the nature of abstractions of extension and level of generality, as each changes or is revised the vantage point will undergo a corresponding change. Put simply, if the abstraction of extension is larger, then more can be seen from the resulting vantage point, and connections may be observed which would be excluded from a narrower extension and a 
correspondingly narrower vantage point.

Abstraction of vantage point is import to the identification of identity and difference. Just as a broad enough abstraction of extension is required to encompass the simultaneity of identity and difference, without an appropriate vantage point, the simultaneity would be impossible to observe. (Ollman, 1993, p. 73). "[O]ne's ability to actually see and therefore to examine either set of qualities depends on the vantage point adopted for viewing them." (Ollman, 1993, p. 73). "Even when the shift in vantage point appears to be slight, the difference in the perspective opened up can be considerable." (Ollman, 1993, p. 73). Ollman notes that change is typically seen as "a comparison of two or more differentiated states in the development of the object or condition or group under examination." (Ollman, 1993, p. 29). Here dialectics, instead, urges us to examine the same state from different views rather than different states from the same view but at different times. This distinction is foundational to the dialectical method. Marx allows us to alter these abstractions throughout the examination when undertaking this examination. (Ollman, 1993, p. 42).

\subsection{Examples of the Use of Dialectics in Geography}

Having examined all three modes or aspects of abstraction, it is important to note that each is relevant not only to the abstraction of the parts but also to the recreated whole. That is, conclusions drawn from a particular abstraction of extension at a particular level of generality likewise must be viewed at the same extension and level of generality in order to be understood, evaluated, and revised. (Ollman, 1993, p. 61). While more than one level of abstraction can be simultaneously considered, it will be necessary to be careful not to mix abstractions of extension and/or abstractions of level of generality in putting the dialectical method to use in this dissertation. "In practice, these three decisions (really, three aspects of the same decision) as to 
extension, level of generality, and vantage point are usually made together and their effects are immediate, though on any given occasion one or another of them may appear to dominate." (Ollman, 1993, p. 69).

In attempting to use these three modes of abstraction, the work of others is also instructive. Sayer's work urging the adoption of post disciplinary studies is relevant in that the dialectical abstraction involved herein will necessarily cross disciplinary boundaries. (Sayer, 2003). First, Sayer proposes avoiding reductionism and inappropriate causal attributions by dismissing the primacy of disciplines and whether ideas can be identified with any particular one. (Sayer, 2003). Such an analysis allows reference to and reliance upon literature outside human geography as additional support for the dialectical abstractions which will be attempted by this dissertation. Issues related to the state and uneven development logically cannot be restricted to the discipline of geography, and making connections with literature outside geography is an opportunity which should not be missed. Ollman notes that Marx would urge us to incorporate existing work into our abstractions, lest we be trapped in isolation. (Ollman, 1993, p. 27).

Consistent with Sayer's suggestion to follow ideas and connections wherever they lead instead of following them only as far as the border of their discipline, this dissertation will transcend traditional boundaries of uneven development literature and geographical literature regarding the state to incorporate into the attempted dialectical abstractions, relevant work regardless of disciplinary boundaries. (Sayer, 2003). Existing literature will be critically reviewed and analyzed, and connections made between theoretical advancements to date, in an effort to reveal the full potential of the dialectical method.

As further justification for the use of dialectics in this dissertation, Ollman 
appropriately notes that "reality is more than appearances, and that focusing exclusively on appearances, on the evidence that strikes us immediately and directly, can be extremely misleading." (Ollman, 1993, p. 11). He continues that "understanding anything in our everyday experience requires that we know something about how it arose and developed and how it fits into the larger context or system of which it is a part." (Ollman, 1993, p. 11). For Ollman concludes that:

After all, few would deny that everything in the world is changing and interacting at some pace and, in one way or another, that history and systemic connections belong to the real world. The difficulty has always been how to think about them, how not to distort them, and how to give them the attention and weight they deserve. Dialectics is an attempt to resolve this difficulty by expanding our notion of anything to include, as aspects of what it is, both the process by which it has become and the broader interactive context in which it is found.

(Ollman, 1993, p. 11). Such a focus on process and connections is well suited for incorporation of Massey's work on networks and Howitt's work on relations into the analysis in this dissertation.

Massey's work is closely tied to spatial practices. Her examination of the tensions between the political, the cultural, and the economic, what she terms the "geometries of power," is important to the definition of spatial practices. (Massey, 1993). Swyngedouw recognized these geometries in his own work. (Swyngedouw, 1997).

Like Ollman, Massey rejects traditional theoretical boundaries of analysis. She sees conceptualizations that are constructed in an introverted, inward-looking, historical way based on origins and that require the drawing of boundaries as problematic. Instead, she recognizes that like people, places have multiple identities. (Massey, 1993). These identities may be implicated in the state's control of and influence over uneven development. These 
aspects of her work shed light on the tensions brought about by rescaling.

Massey's alternative interpretation suggests examining points in the intersection of social relations. The uniqueness of place, or a locality, for her is formed by particular interactions and mutual articulations of social relations, social processes, experiences and understandings, in a situation of co-presence, but where a large proportion of those relations, experiences, and understandings are actually constructed on a much larger scale than what we happen to define for that moment as the place itself, whether that be a street, a region, or even a continent. (Massey, 1993). Massey urges us to look at moments in networks of social relations. (Massey, 1993). This interpretation is closely tied to the abstraction of vantage point which serves as one of the foundational aspects of dialectics.

Howitt advances that concepts are most meaningful when made real by understanding the complex and dynamic relationships and processes in context, a position that, like Massey, is closely tied to the examination of spatial practices. (Howitt, 2003). Howitt recognizes that tension between globalization and locality research was often a product of research paradigms that failed to deal with the simultaneity and complexity of power relations, identity, and difference that Massey saw as challenging naive notions of space. (Howitt, 2003). Such naive notions of space made any consideration of concepts such as state involvement in place building, the politics of identity, power relations, and uneven development impossible, because those conceptions of space and scale did not allow for examination of the relations between scales. Howitt argues that it is precisely the failure to undertake meaningful analysis across scales that has been problematic in operationalizing scale as a fundamental concept with practical rather than merely rhetorical value. (Howitt, 2003).

Merrifield's work is more directly connected to state spatial practices. Neither 
Massey nor Howitt examine the spatial practices of the state, whereas Merrifield indirectly implicates state spatial practices in his examination of the relationships between space and place. Merrifield has already successfully used dialectics in the spatial context when he examined LeFebvre's spatialized dialectic and theorized the specific dialectics of space and place. (Merrifield, 1993, p. 519). Merrifield argues against a Cartesian viewpoint with its dualism of place. He argues there is no polarity between subjective and objective realms of place. (Merrifield, 1993).

Merrifield provides a foundation for the examination of spatial practices, because spatial practices implicate both aspects of space and place. Traditionally, place has been thought of as state constructed (Tuan, 1977). Merrifield segues us from state constructed place to capital space in discussing the capitalist space-place relationship. (Merrifield, 1993. p. 520-521). Merrifield suggests that space is not the abstract with place being more concrete, and he urges us to consider space and place together.

For Merrifield there is no real distinction between circulating and fixed capital; they are just different moments in capitalism. As a result, his theorizations transcend more traditional conceptualizations of place. He notes that when capitalism takes place somewhere, capital fixity results which forms "place." (Merrifield, 1993). This notation recognizes capital's construction of place and capital's identity and difference where capitalism itself is both a thing (produced space) and a process. For Merrifield, social space is a form of production itself. The interpenetration of opposites is recognized when Merrifield notes that this capital form can be both a space and a place at the same time. (Merrifield, 1993).

Merrifield also sheds light on the production of space and place as spatial practices by noting that capitalist space internalizes conflict. Social forces and social conflict are 
"inscribed in place," and there is a tension between the use of place for social purposes and for domination, as will be seen in the case study of Appalachian land acquisitions. The bottom line is that the relationship between space and place is understood by the relation between fixed and circulating capital. Fixed capital is place. Circulating capital is in space. The spatial practices that determine where and when each can reside are the subject of this dissertation.

Ollman notes that a fully adequate theory of the state, which would answer all of the important questions, could only be constructed by integrating aspects of the dialectical method. (Ollman, 1993). In this dissertation, the dialectical method will be applied to capital accumulation strategies and state spatial practices to attempt a more complete theorization of the state's role in uneven development. Obviously conceptual development of a comprehensive theory of the state would require abstraction of additional elements not selected for inclusion herein. Dialectics is well suited to these two analyses, however. With regard to the newly developed concept of flexible rescaling, the preference of the dialectical method for explanation of the various forms change assumes and why it appears to have stopped, instead of a preference to explain why something starts to change, is particularly well suited. "[T]he subject of dialectics is change, all change, and interaction, all kinds and degrees of interaction." (Ollman, 1993, p. 23). The changes predicated upon dualistic capital accumulation strategies and brought about by flexible rescaling are at the heart of this dissertation. 


\section{Chapter 6}

\section{A New Examination of the State's Role in Uneven Development}

While Brenner, Smith, and Harvey, attempt theorizations of the state's role in uneven geographic development, and while non-geographers such as Marxist social theorists like Milliband and Poulantzas also attempted to explain the role of the state in uneven development, the state's spatial role remains under theorized. No geographer or non-geographer has adequately explained how the state actively controls uneven development through its spatial practices.

The rise of neo-liberalism has not diminished the importance of the state as many both liberal and conservative theorists have surmised. The state intervenes in the workings of the affairs of capital to assist capital just as it always has. (Harvey, 2006, p. 28). Such continued intervention makes examination of the state's spatial role, and how that role is fulfilled, more important than ever.

The state actively employs rescaling as a spatial practice to control and impact uneven development for the benefit of capital, but it does so without formally restructuring. The state employs flexible rescaling inherent in the state system to control uneven development.

Flexible rescaling is a new concept that explains the state's ability to maintain control over influences on capital accumulation to assist capital, particularly in times when public consent for its interventions wane. "The preferred form of governance is that of the 'public-private partnership' in which state and key business interests collaborate closely together to coordinate their activities around the aim of enhancing capital accumulation." (Harvey, 2006, p. 27). Such partnerships are often accomplished by flexible rescaling. "[L]arge corporate capitalist interests typically collaborate with government power in policy making as well as in 
the creation of new [] institutional arrangements." (Harvey, 2006, p. 26). Flexible rescaling represents one way that this collaboration is accomplished. In terms of flexible rescaling, the "policy making" referenced by Harvey is an allusion to governmental policy, whether or not reduced to written law, which allows the state to intervene in the capital process to the benefit of capital.

The concept of flexible rescaling is equally applicable across scales and for the state's assistance with accumulation by dispossession both in its original or primitive form as well as when it is used to stave off crisis, as Harvey recognized. The case studies which follow this preliminary conceptual explanation of the concept will develop further, explain, and illustrate the workings of flexible rescaling generally through an examination of state supported land practices in Appalachia.

The basic premise of flexible rescaling is that state power cannot always be deployed at the same scale to assist capital. Harvey alluded to flexibility as a harbinger of rescue for capital when he noted:

The free mobility of capital between sectors and regions is regarded as crucial to reviving profit rates and all barriers to that movement (such as planning controls) have to be removed except in those areas crucial to "the national interest" (however that may be conveniently defined). The watchword of the neoliberal state is, therefore, "flexibility" (in labor markets and in the deployment of investment capital).

(Harvey, 2006, p. 25). While here Harvey falls short of extending this flexibility to rescaling of the state as an active spatial practice, he alludes to capital's need for flexible rescaling of its own actions to ensure continued expansion. The flexible rescaling of state power proves just as necessary and, as will be seen, functions much the same way toward the same ends. 
Flexible rescaling comes in two forms: stratified shifts in power up and down and lateral intra-scaler shifts in power. While initial deployment of state power, whether by coercion or force, may be best placed at one scale, the need may arise (often through public withdrawal of consent) to devolve that state power at a different scale to achieve the same goal. Similarly, while it may have been initially sufficient to deploy state power at only one scale, the need may arise for additional concurrent pressure or influence from another scale to assist with the accumulation process. The converse is obviously also true: state power imposition from more than one scale may be the initial push for assistance to capital, only later for the state to recognize that concentration of the state's power at a single scale would be better placed. The inherent flexibility of the system is what allows for these stratified shifts of power up and down within the system as well as for lateral transfers of power within a particular scale that also amount to flexible rescaling. Factors that influence these decisions, particularly consent, will be explored below.

As discussed above, it is well established that capital accumulation takes two forms: accumulation by dispossession and accumulation by expanded reproduction. Within accumulation by dispossession, two distinct forms emerge. First, the primitive or initial form of accumulation by dispossession is long recognized by traditional Marxist theory and will be explored here in terms of eminent domain. Second, in The New Imperialism, Harvey recognized a second use for accumulation by dispossession- to stave off crises of over-accumulation once accumulation by dispossession has transitioned into accumulation by expanded reproduction, and once accumulation by expanded reproduction is firmly underway- and will be explored here in terms of mountaintop removal. Briefly, the need for such accumulation by dispossession occurs when a spatio-temporal fix is not otherwise available to bail capital out of impending crisis. 


\section{Chapter 7}

\section{State Flexible Rescaling and Land Acquisition: Examples from Appalachia}

Having defined flexible rescaling as the state's ability to maintain control at differing scales over influences on capital accumulation to assist capital, particularly in times when public consent for its interventions wane, we can look at examples of flexible rescaling in Appalachia as an illustration. Three concrete examples of state flexible rescaling in Appalachia are examined herein.

To better understand these examples, we must recall that from the new theory of state flexible rescaling, we know that the state actively flexible rescales in two ways, by action and by inaction. We know that the state does so to benefit capital when power retention at the current scale or an anticipated shift in power would not serve the interests of capital. We also know that the system is inherently flexible; that is, the system has the power to change the scale of state action without formal restructuring of the state.

In examples within Appalachia we can see the state actively flexibly rescaling in two ways, by action and by inaction. First, by action we can see the state taking affirmative state actions at one scale when the anticipated scale does not benefit capital. In such cases, when capital expresses or demonstrates a need or a benefit that the state cannot fill at that scale, the state will actively shift power up or devolve power down or move power laterally to accomplish for capital what capital needs. Second, similarly, state inactions can amount to state flexible rescaling. In such instances of state inaction, we see the state refusing to act resulting in state spatial practices that are inactions. In such cases, when state inaction occurs at a time when there would have been a natural shift in power upward or downward that would not have benefited capital, then the state's inaction amounts to an active state spatial practice that is flexible 
rescaling.

While the examples illustrate these two state spatial practices of action and inaction that amount to state flexible rescaling that benefits capital, they also illustrate the flexibility inherent in the system. The examples illustrate the flexibility inherent in the system in different ways. First, the judiciary with its levels of appeal has a built in spatial distribution that allows power to move upward by appeals and downward by remands and through Court orders mandating further action at a lesser scale. Second, the executive power system of the local, state, and federal government has the same flexibility inherent in the system allowing shifts of power within the executive branch between these scales inherent in the system.

First, land acquisitions at the time of the early transition from subsistence farming toward a more complete industrialization illustrate changes in the executive system that facilitated state accumulation by dispossession. Second, land acquisitions by eminent domain, particularly through the definition of public use and the battle for high voltage power transmission lines within Appalachia illustrate changes in the judiciary system that facilitated additional accumulation by expanded reproduction in Appalachia through devaluation and redistribution. Third, land acquisitions for mountaintop removal illustrate a spatio-temporal fix that staved off crisis in industry in Appalachia.

7.1 Land Acquisitions Illustrating Flexible Rescaling: Accumulation by Dispossession and the Transition to Early Industrialism

The state's active role in flexibly rescaling is evident during the development of accumulation by dispossession in Appalachia during the early transition to industrialism where we see two primary state spatial practices at different scales working in tandem to benefit capital: first, the state spatial practice of actively creating and maintaining a land recording system at the local scale that allowed capital land agents to buy and retain land resources cheaply and that 
simultaneously created a cheap labor force for capital as a result of the dispossession and, second, a state spatial practice at the federal scale where the resulting industrialization is regulated by the federal government in a way that reduces competition and allows capital expansion through the continued exploitation of that land and labor.

Harvey has provided us with examples of accumulation that allow us to examine flexible rescaling here. The early transition examined here was specifically noted within the examples he provided. (Harvey, 2006, p. 43). Harvey included within his examples of accumulation by dispossession "commodification and privatization of land and the forceful expulsion of peasant populations" and "commodification of labor power and the suppression of alternative (indigenous) forms of production and consumption." (Harvey, 2006, p. 43). Harvey did recognize that the "state, with its monopoly of violence and definition of legality, plays a crucial role in both backing and promoting these processes," but how that role was played was never defined before now. (Harvey, 2006, p. 43).

Harvey's theorization can be extended here where we see the state's role clearly in the example where Appalachian subsistence farmers sold their land to capital's land agents at a local scale who recorded the transactions using recording system created and maintained as a state spatial practice at that local scale that benefitted capital. Those prior land owners then transitioned into wage labor, having been dispossessed with the state's aid at the local scale of their most powerful resource- their land. As they become new wage laborers, we see the state flexibly rescale power to continue to benefit capital. Having exhausted the state's power at the local scale available to benefit capital, those new wage labors are then regulated by a second state spatial practice at the federal scale following passage of capital-friendly legislation regulating the industrial workplace. We see the state recalling its power from the local scale to 
the federal scale to allow additional benefit to capital which would not have been available had power not been actively shifted - or flexibly rescaled- by the state.

Two state actions, flexibly rescaled from the local scale to the federal scale were at play. On the local scale, land sales made possible and sanctioned by state actions left the land behind for the use and benefit of absentee landowner capital as a cheap resource and left the inexpensive labor created by dispossessing those landowners at the same time. On the federal scale, following the flexible rescaling, the laborers and their working conditions are regulated by the federal scale when control at the local scale becomes impractical. Note here that the flexible nature of the system is revealed by the example where the state is not required to restructure in order to change the locus of power.

Specifically exemplified, most generally speaking, during the period from approximately the 1880's through approximately the 1930's, like much of Appalachia, West Virginia underwent a transformation from a partially agrarian self-sufficiency or "competency" state, where development and commercialization was uneven and a lack of transportation, capital, and technology was pervasive to a more complete industrialization. (Lewis, 1998). By 1930, most Appalachian income had shifted to non-agricultural employment. Mountaineers were previously living off the land, largely independent of the state’s influences. But, by 1930 many had taken jobs in mining, logging, textiles, and public work. (Eller, 1982, p. xix).

Appalachian scholar Paul Salstrom argues that the decline of economic selfsufficiency in Appalachia is also result of land destroying agricultural practices such as slashand-burn farming, poor timber practices, the destruction of the Civil War, and New Deal politics. (Salstrom, 1997). Here we can see the state's actions and inactions at play again though the second active state spatial practice referenced above. The 1933 National Industrial Recover Act 
(NIRA), a piece of legislation at the national scale, formed an important spatial practice, and the subsequent Wagner Act (the National Labor Relations Act) in 1935, another piece of legislation at the national scale that formed an important spatial practice, increased coal prices and increased wages which, in Appalachia, translated into increased automation of coal loading and decreased jobs, slowing the pace of industrialization with regard to workers, but continuing its ascent with regard to capital, (Salstrom, 1994). This state spatial practice at the federal scale of enacting national legislation was promoted as helping workers, but it actually helped capital in the end as capital found mechanization in the wake of industrial decline.

While NIRA created the federal public works program, it also allowed the federal government through its executive branch to permit concerted capital action and monopoly as a means of stimulating the economy. Specifically, NIRA provided that "the President is authorized to enter into agreements with, and to approve voluntary agreements between and among, persons engaged in a trade or industry, labor organizations, and trade or industrial organizations, associations, or groups, relating to any trade or industry, if in his judgment such agreements will aid in effectuating the policy of this title with respect to transactions in or affecting interstate or foreign commerce.” (NIRA, 1933). The stated policy of NIRA included "remov[ing] obstructions to the free flow of interstate and foreign commerce which tend to diminish the amount thereof," "promoting the organization of industry for the purpose of cooperative action among trade groups," "promot[ing] the fullest possible utilization of the present productive capacity of industries," and "avoid[ing] undue restriction of production." (NIRA, 1933, Sections 1-3). These federal scale spatial practices of allowing monopoly follow the stated policy of NIRA, the development of which policy actually exemplifies a state spatial practice itself. 
But the effects of these active state spatial practices of flexibly rescaling power to benefit capital were not the only additional state spatial practices ongoing at the time. If we alter our vantage point again, we can see the state's inaction (itself another active state spatial practice) at the federal scale and at the local scale. This inaction was allowing poor economic conditions to persist and allowing uneven development that benefitted capital by maintaining the resource pool in under-developed areas to persist.

Salstrom posits that economic dependency in Appalachia persists even until today, because Appalachian farmers were forced, during the period of rapid industrialization, by declining living conditions, to take wage earning jobs such as these, illustrating how state spatial practices exercised long ago at two differing scales have a continued impact. (Salstrom, 1997). He notes that, as full time farmers, during the late 1800 's to early 1900 's, they were growing poorer. Salstrom also employs our changed vantage point to alert us to this other state spatial practice concurrently at play. He argues that inept federal scale welfare administration and absentee landownership and control negatively impacted Appalachia during the process of industrialization. (Salstrom, 1997). According to Salstrom, when people needed help on a federal scale from the state, it was the state's inaction that formed a concurrent spatial practice at the federal level of allowing deprivation that also forced self sufficient farmers toward capital. The lack of federal welfare administered by the national government at that time was a state spatial practice at the federal level that forced individuals to work in the coal fields and in the factories despite the poor industrial and economic conditions that the prior state spatial practice of legislation enactment explained above had created. This additional spatial practice of inaction also allowed capital to use those people as an inexpensive resource, because of their artificially created economic need. 
Specifically, Salstrom argues, with a peripheral rather than a colonial economy thesis, that reduced wage demands of Appalachian residents created by the state's action of withholding welfare administration at a local scale had the result of subsidized company wages and served to transfer Appalachia's wealth outside of the region. (Salstrom, 1997). Here the state can be seen rescaling wealth within the capital pool so that uneven economic development persists. Salstrom argues that Appalachia's early regional scale economy benefitted more from its prior self-sufficient subsistence farming than its entry into the capitalist money-based economy during this period of more rapid industrialization. (Salstrom, 1997). However, when wage labor failed to support fully the mountaineers as the federal government had through the state action of withholding the administration of welfare and mountaineers looked back to family farms when industrialization slowed, the industrial economy that the state had supported made a profitable return to subsistence farming impossible. (Salstrom, 1997). As a result we see this concurrent state spatial practice of inaction at play benefitting capital expansion.

When examining the early industrialism of Appalachia, the flexible rescaling of the state actions and inactions that amounted to active state spatial practices can be easily seen from a number of different vantage points. The flexibility inherent in the system is revealed as actions at various scales combine to create the dual capital benefit of cheap labor and cheap resources that resulted in the transition to industrialism.

\subsection{Land Acquisitions Illustrating Flexible Rescaling: Eminent Domain}

If we fast forward to modern day Appalachia, we can more closely examine two cases of ongoing dispossession of land and resources which will further illustrate, explain, and develop the theory of flexible rescaling conceptualized here. First, we see classic accumulation by dispossession as a means of transferring ownership of resources to allow for classic 
accumulation by expanded reproduction. State spatial practices support intrastate shifts in power among scales, as illustrated when we examine eminent domain and the expansion of the definition of public use as well as its implications for electrical power transmission in Appalachia.

In terms of eminent domain generally, accumulation by dispossession can be seen within Appalachia occurring as a predicate to accumulation by expanded reproduction, but eminent domain is an even better illustration of the process of flexible rescaling at work. Recall that Milliband refers to the state as an "instrument" or "tool" available for use by capital to ensure the maintenance of conditions of uneven development beneficial to capital. Here we see the state used by capital in that way. When capital was unable to secure land on its own through favorable terms that amounted to dispossession, we see capital extend itself into the legal arena to secure the state's assistance in obtaining the devalued property necessary to proceed with capital accumulation.

\subsubsection{TrAIL and High Voltage Transmission Lines in Appalachia}

Eminent domain generally, as well as specifically with regard to electric transmission lines within Appalachia, acts as an example and helps develop the theory of flexible rescaling. State and capital are intertwined and/or the state is used at varying scales as an instrument of capital to promote eminent domain. Note that once again the flexibility required and employed is inherent in the system. Flexible rescaling, because of its flexible nature, can again been seen occurring without requiring formal restructuring of government.

Eminent domain is best explained by the federal government's most prominent recent eminent domain decision handed down: $\underline{\text { Kelo }}$. Kelo v. City of New London. In Kelo, the United States Supreme Court's decision forms a judicial state spatial practice at the federal scale 
that sanctions the process of taking private land for what is deemed "public benefit." In Kelo, these "benefits" are couched in terms of urban growth and renewal- in short development and redevelopment. In this instance, flexible rescaling, initially seen as the primary justification for accumulation by dispossession for purposes of accumulation by expanded reproduction, is both justified and sold as beneficial to the public good. Eminent domain, it should be noted, is one of the clearest examples of flexible rescaling, as is the development of many legal issues, because the inherent flexibility to rescale is perhaps most transparent when we examine the judicial system where power flows more freely and in a logical structure designed to allow such flows.

“'Public use' used to have simple meaning in many quarters: A use was public if the public used the property.” (Claeys, 2004, p. 2). Recent case law has seen a retreat from “public use” and the development of a sister theory of "public benefit” which allowed broader rights for taking land, as well as allowing the development of consent through a new paradigm. It was under the "public benefit" shift that the taking of land for urban redevelopment, because of blight, and by capital rather than by the state was sanctioned. We see this "public benefit" employed to justify power lines, with a concurrent shifting of power flexibly between scales as a state spatial practice to assist capital with accumulation. Harvey's grid of spatial practices is useful in examining how flexible rescaling occurs.

If we return here to Harvey’s grid of spatial practices, and apply it to the state, we first recall that the grid examines how three different spatial practices work. (Harvey, 1987). Those three spatial practices are experienced or material spatial practices, perceived spatial practices, and spaces of representation or imagined spatial practices. (Harvey, 1987). Each can be applied easily to the state to allow analysis of the state's active spatial practices and to allow development of the theory of flexible rescaling. 
In terms of the state's spatial practices, first, experienced or material spatial practices are physical flows and transfers made by the state across space and time, illustrated here by the transfer of property rights. Second, perceived spatial practices are representations of space or signs and significations put in place by the state that allow transfers to be understood by the populace, here the creation of a "public benefit" where either none previously existed or where none exists in actuality. Third, imagined spatial practices or spaces of representation are mental inventions of new meanings for spatial practices formed by the populace as a result of state imagined spaces as a means of developing or maintaining consent to the state's spatial actions, here the public's buy-in to the state's "public benefit.” In the spaces of representation we can see consent develop as the populace shifts from the esoteric theory of "public benefit" to an internalized theory of self-benefit.

We can also use Harvey's grid to examine how these three conceptualizations of spatial practices impact how people and how the state see and use space. Recall that when applied to individuals, the grid looked at how people see and use space in four different ways. (Harvey, 1987). Application of the theory to the four ways the state sees and uses space and to the four ways people see and use space as a result of the state's active spatial practices allows a further development of the theory. These same four ways space is used can be applied to the state and to people's spatial reactions to the state simultaneously. Accessibility and distanciation, appropriation of space, domination of space, and production of space can all be applied to the state's active spatial practices within this example, as well as continuing to be simultaneously applied to individual spatial practices.

First, accessibility and distanciation are the measure of the degree to which friction of space has been overcome by the state to accommodate capital's interactions. As the 
state rescales, for example from state regulation to federal regulation as we see in the threatened state rescaling of power through a shift of approval power for the TrAIL high transmission electrical lines from the state public service commissions to the appeal for federal approval of the line which was (and remains) waiting in the wings in the event capital's hopes of expansion are dashed by a failure of all involved states to approve, route, and permit the lines in question, friction is decreased and public consent grows. Harvey referred to distance as both a barrier to and a defense against social interaction. (Harvey, 1987). Here we can see distance or scale used as a barrier and a defense to active state spatial practices in the form of regulation.

Second, appropriation of space is how space is taken or assumed by individuals. Here we see how the state's active spatial practices allow capital to take or assume space through the promulgation of rules and case law that allow for eminent domain in circumvention of the apparent limitations of the Fifth Amendment. The state's approvals (both in terms of allowing the process to proceed and in approving the process once it is underway) amount to spatial practices that allow space to be taken or assumed by capital for capital's benefit, whether or not couched in terms of public use and/or public benefit.

Third, domination of space by individuals or powerful groups, as defined by Harvey, is the legal or extra-legal means to control space. There is no explanation required to allow the extension of this element to the state's spatial practices.

Last, production of space is how new systems and representations are formed. Here we see how the individual or populace image of uneven development is molded by active state spatial practices that achieve Gramsci's hegemony through state sanctioned accumulation practices. The populace forms a new impression of eminent domain when it is internalized, resulting in achievement of consent. 
Using this spatial grid, and applying it to active state spatial practices, we can better use the case of power lines as an illustration as well as to further develop a theory of flexible rescaling of power which continues. When we change our perspective and/or our vantage point, the actions of the state can be seen in the same framework developed by Harvey to examine individual spatial practices. When we examine the facts and procedural history of Kelo, the applicability of Harvey's grid to these state spatial practices becomes even more apparent.

Returning to Kelo, which was introduced briefly previously, recall generally that

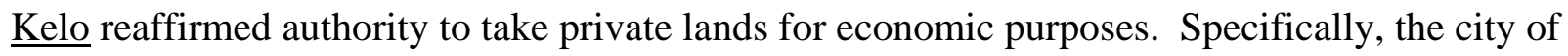
New London, Connecticut, used its eminent domain powers to take temporary ownership of private property before selling the property to private real estate developers.

Back in February 1998, Pfizer, Inc. announced that it was developing a global research facility on a site adjacent to the neighborhood where Susette Kelo and others lived. In April 1998, the city council of the city of New London granted the request of the New London Development Corporation ("NLDC”) to prepare a development plan for the area in question. It should be noted that the NLDC was a private, non-profit corporation formed in 1978, allegedly to assist the City in planning economic development for the city. The plan created included a waterfront hotel, a conference center, and approximately 80 new private homes, among other “economic developments” denominated as for “public use.” According to the plan, the NLDC would own the land located in the development area but would lease it to private developers for \$1 per year under a 99 year lease.

The residents of New London, led by Susette Kelo, wanted to challenge the development and the justification for it. Under Connecticut law, however, property owners can challenge only the amount of compensation offered, not the right of the government to take their 
property, which is why the case was brought under the Takings Clause of the United States Constitution. In response to the initial challenge, the city, through the NLDC argued that the sale and subsequent development of the land would foster economic development and create a new tax base and, therefore, did not violate the Takings Clause. Susette Kelo, on her own behalf and on behalf of and others who also had property taken by the city of New London sued the city in Connecticut state court. Susette Kelo argued, on behalf of all of the property owners, that their rights under the Fifth Amendment's Takings Clause were violated. The Takings Clause provides “...nor shall private property be taken for public use, without just compensation.” (US Const., Amend. V.). The Fifth Amendment did not create the national government's right to use eminent domain power or to allow others to use it. All the Fifth Amendment did was to limit taking to “public use.” In 1791, when the Fifth Amendment was added the battle over the ultimate definition of "public use” was yet to be waged.

The battle was waged, largely, when Susette Kelo’s case was tried and, with regard to certain land owners the Superior Court's Memorandum opinion indicated that the City had not demonstrated that the land would be used for public use. The Memorandum opinion was appealed. The opinion of the Supreme Court of Connecticut was entered on March 9, 2004. A four-justice majority of the Court held that none of the challenged condemnations violated the United States or Connecticut Constitutions. Thereafter, a motion for reconsideration was filed by Susette Kelo which was denied on April 20, 2004. Susette Kelo then appealed the case to the United States Supreme Court pursuant to the Supreme Court's federal question jurisdiction. 28 U.S.C. § 1257(a).

The case was briefed and argued before the United States Supreme Court. Justice John Paul Stevens delivered the majority opinion of the Court on Thursday, June 23, 2005, upholding 
the Connecticut Supreme Court's decision 5-4. Kelo v. City of New London. The Court held that the city's taking of the private property of Kelo and others and the city's subsequent sale of that property to private real estate developers did in fact qualify as a "public use" within the meaning of the Takings Clause of the Fifth Amendment of the United States Constitution. Kelo v. City of New London. The Court noted that the city did not take the land solely to benefit a certain group of private individuals. Instead, the Court decided that the City was following a legitimate economic development plan it had created. As a result, the United States Supreme Court, in its own state spatial practice, which had been rescaled from the Connecticut State Supreme Court, held that the taking at issue in Kelo qualified as "public use" even though the land was not going to be used by the public. The spatial practice was determinative of the issue of whether the Fifth Amendment required "literal" public use. The majority of the Court held that broader and more natural interpretation of public use as 'public purpose' was sufficient, and the application of the doctrine of eminent domain was altered. Kelo v. City of New London.

Simplified, the Taking Clause basically guarantees that government will not take private property for public use without just compensation. Here the property owners argued taking private property and selling it to private real estate developers was not a public use. The property owners argued that, unlike in blight cases, where arguably the public would benefit from condemnation, there is nothing in the act of condemning non-blighted properties that constitutes a public purpose. The Connecticut State Supreme Court disagreed and ruled for the city of New London. The United States Supreme Court ultimately upheld that ruling. The rescaling of power necessary to defend the legitimizing of the state's spatial practice is inherent, and the flexibility inherent in the system by which the rescaling occurred is well illustrated.

While, jurisprudentially, it appears clear that the Fifth Amendment to the United 
States Constitution should limit how and when the government's eminent domain power can be exercised, when "public good” or "public benefit” is involved, the Fifth Amendment frequently is not interpreted by Courts to limit or preclude eminent domain invocation. Phrases such as "blight remediation,” “economic development,” “renewal,” or "urban revitalization” have all been cast as "public use" or "public benefit" sufficient to allow the circumvention of what would appear to be clear Fifth Amendment dictates. Moreover, what constitutes “just compensation” has also become a matter of legal debate as we see Harvey's devaluation for accumulation at play as a means to reduce what "just compensation" would constitute in the face of claims of economic blight. In the end, when and how eminent domain can be used and what constitutes “just compensation” are factors determined by the state through either the legislature or the courts, the decision as between them also being made as a part of the flexible rescaling theorized herein.

These political entities acting in the "public interest” or determining "public use” frequently act in the best interest of capital while declaring "public use.” When he contends that "the whole history of legal decisions which, in most bourgeois democracies, favor the rights of private property . . . over social justice," Harvey is somewhat short-sighted, failing to recognize that the tendency of the judiciary depends on whose private property rights are being eschewed. (Harvey, 2006, p. 51). Elsewhere, his recognition that privatization entails not only private but class privileged domains arguably accounts for this shortcoming. (Harvey, 2006, p. 45). In the above described $\underline{\text { Kelo }}$ case the state flexibly rescales its judiciary power to provide capital the benefit of subsidized economic growth through sanctioned dispossession in favor of capital.

The rationale of the Kelo case has been extended into Appalachia through the routing and approval of power transmission lines. The federal government, in that instance, 
initially made a scalar decision, employing an active spatial power, that it would be unable to justify the need for power lines that would be built if privately owned land was dispossessed. Political power, as a result, was spatially devolved to the regional scale to make such a justification. This devolution of power constitutes an active spatial practice of the state flexibly rescaled to the regional scale.

At that regional scale, PJM entered the picture in Appalachia to sell theories of instability, national insecurity, and rolling blackouts to justify the building of the line altogether. Another rescaling can be seen where approval of the projects, siting of the lines, and permitting was devolved further by an active state spatial practice from the regional scale to the state scale to state Public Service Commissions or Public Utility Commissions. Finally, construction of the lines would have to occur within the states. State public service commissions got involved to approve the routes for the lines and to bolster and ratify PJM's claim of need for a line, but an obstacle arose at the local level.

Strong local opposition to the building of the lines meant that states, either eager to or required to satisfy their constituents to maintain power, might not approve the routing of the lines or ratify the need for the lines. Now, the approval processes, which included rerouting of some lines to quash opposition and build at least tacit consent, resides in the states. But as a final state spatial practice, active flexible rescaling is employed from a system with inherent flexibility. Additional flexibility within the state to rescale again exists in the system in the form of federal backstop authority at the federal scale.

Section 368 of the Energy Policy Act of 2005 (EPAct) directed the Federal Secretaries of Agriculture, Commerce, Defense, Energy, and the Interior to designate corridors for electricity transmission and distribution facilities on Federal lands in 11 contiguous Western 
States (Arizona, California, Colorado, Idaho, Montana, Nevada, New Mexico, Oregon, Utah, Washington, and Wyoming), to perform necessary environmental review, and to incorporate the designated corridors into relevant agency land use and resource management plans. The secretaries are to consider national need for additional infrastructure and to take actions (spatial practices) to "improve reliability, relieve congestion, and enhance the capability of the national grid to deliver energy.” EPAct also allowed the secretaries to identify corridors in the other 39 states and allowed the secretary to engage in spatial practices which would "expedite processes" for energy projects in the corridors, thereby providing federal legislative authority for federal backstop powers in the event the devolution of power to the states for approval of the electrical transmission line projects was unsuccessful in allowing capital expansion and flexible rescaling was again required. It should be noted that Section 368 of EPAact also instructs agencies to form corridors for oil, gas, and hydrogen pipelines.

As a result, by passing the Energy Act of 2005 into law, the state, at the federal government scale, retained the right to declare national energy corridors if the states failed to approve the need for and routing of a high voltage transmission line like the one at issue with the TrAIL project. Once declared, the state could flexibly rescale and the federal government could reassume power from the states to approve the process, ultimately flexibly rescaling to approve both the building and the routing of the lines if states would not.

In this example, the power to take the land needed for the lines, the power to declare a need for the lines, and the power to control the routing of the lines can be seen manifesting itself to the benefit of capital at various scales at various times to ensure the building of the transmission lines in question. The state's active spatial practice of both changing the scale of power and of building into the system a flexible means by which the scale of power 
could be changed if necessary amounts to flexible rescaling in action.

In this example we see a flexibility created in the system to anticipate a potential need to rescale. Whereas the judiciary and executive branches were created with flexibility inherent, the regulatory system on the executive side also possesses the ability, through employment of the legislative branch when laws are enacted or on its own through rule-making powers granted to the executive to create flexibility within the system in case power to regulate needs shifted. When EPAct included federal backstop authority at the federal scale, and when PMJ was created at the regional scale, additional flexibility was built into the system by legislative action so that transfers of power are possible if necessary.

Thereafter, where it is thought to be most efficient to act on a federal level unnoticed, then power is flexibly rescaled and devolved at that scale. When it is thought to be most efficient to act on a regional level, then power is flexibly rescaled and devolved at that scale to built consent by creating a general need for the project. And when it is thought to be most efficient to act on a state level, fracturing opposition and obtaining further consent, this time by force if necessary, then power is flexibly rescaled and devolved at that scale. Importantly, note that when the chosen scale reveals itself not to be the most efficient without opposition, then a flexibility inherent in the system is used to redistribute the power to sanction or approve the decision to another scale by state spatial practices that amount to flexibly rescaling.

Capital has become so dependent on this flexible rescaling and on state support for capital accumulation and its corresponding uneven development, that capitalists assume their expansion requests will be fulfilled. "Then we'll take it," she said, when one West Virginia landowner asked "what if we do not want to sell [our property to the power company]?" (Dominion Post, April 16, 2008). This demonstrated dependence on flexible rescaling to get the 
job done shows how flexible rescaling operates unseen to guarantee to capital the ability to transition seamlessly between forms of capital accumulation to create continuing uneven development.

The eminent domain practices attempted here, with high voltage power transmission lines, reflect Harvey's realization that "[a]ccumulation by dispossession entails a very different set of practices from accumulation through the expansion of wage labor in industry and agriculture." (Harvey, 2006, p. 52). Harvey notes that "dispossession ... is fragmented and particular-- a privatization here, an environmental degradation there, a financial crisis of indebtedness somewhere else." (Harvey, 2006, p. 52). The linear path of dispossessions in electrical transmission line disputes over miles, counties, and states fragments the possibility of effective resistance and diminishes the ability to coordinate resistance across regulated areas. This inability to mount effective resistance is characteristic of accumulation by dispossession as Harvey defined it. Specifically, Harvey noted that accumulation by expanded reproduction "gave rise to an oppositional culture (such as that embedded in trade unions and working class political parties)." (Harvey, 2006, p. 52). Here, with fragmented dispossession, opposition organized around shared culture is diminished. Examining this process from the vantage point of the state, capital, and the landowners potentially impacted by the construction of the lines allows a clearer picture of when, how, and why power is shifted by the state.

The shift in the definition of public use discussed in this example and the active state spatial practice of flexible rescaling that accompanied that shift with regard to power lines reflect the fact that "[c]apitalist activity is always grounded somewhere. Diverse material processes (physical, ecological, as well as social) must be appropriated, used, bent and re-shaped to the purposes and paths of capital accumulation." (Harvey, 2006, p. 78). The United States 
Supreme Court did just that with its Kelo decision and in the case of TrAIL and the power line battles that followed it.

\subsubsection{Mountaintop Removal in Appalachia}

If we examine a second resource dispossession within Appalachia, different aspects of flexible rescaling, as well as flexible rescaling in a different context-that of accumulation by dispossession to stave off a crisis, can be developed. We can examine Harvey's second kind of accumulation by dispossession — that employed to stave off crisis—as employing multi-scalar transitions that amount to flexible rescaling as an active spatial practice of the state when we examine mountaintop removal in Appalachia. In examining mountaintop removal we also can see, for the first time, lateral flexible rescaling, illustrating another aspect of the system's inherent flexibility. Unlike in the other examples where power is pushed up or down to benefit capital interests, here power is shifted laterally to benefit capital interests, as will be more fully explored below.

Mountaintop removal appeared as an industrial advance that rose from the continuing unevenness in coal that has marked Appalachian industrialization. This unevenness set the stage for the emergence if this new state supported advance. Here, the historical context of the development of the coal industry in Appalachia proves important.

Despite dating Appalachian industrialization squarely between 1880 and 1930, Eller recognizes that as early as the 1790's small quantities of coal were mined in some areas of Appalachia. (Eller, 1982, p. 4). In fact, as early as the 1740 's, rich coal and iron deposits were documented in the mountains. (Eller, 1982, p. 44). After 1900, the practice of combining coal and timber interests in the land companies to fully exploit the available resources of the land, however, changed the character of the coal industry. (Eller, 1982, p. 95). The timber industry 
declined rapidly after its apex in 1909, (Eller, 1982, p. 109) and the coal industry rose to the industrial forefront.

A major source of population increase between 1880 and 1930 was attributable to the coal boom. (Eller, 1982, p. 134). The demand for coal increased steadily after 1900. (Eller, 1982). In 1917, the Scotts Run coal field in northern West Virginia opened with an industrial fervor largely unmatched, sparking early coal primacy in the northern coal fields. By 1932 the industry had virtually collapsed everywhere. The five mile long hollow of Scotts Run was one of the most intensely developed coal districts in the United States. (Lewis, 2002). As a result of such development, as discussed in the first example, many West Virginians left their agricultural living for coal mining. At the same time, Appalachians outside West Virginia were not benefitting yet from coal's industrialization of the mountains. It would take time for the coal industry to spread south with increased wartime demand.

When post-war demand decreased, the labor-capital conflict intensified. (Lee, 1969). This conflict, like the industry generally, also developed unevenly. Worker cooperation through labor unions organized along the class divide was viewed as radical. (Lewis, 2002). The state attempted to crush such cooperation, and it did so under the banner of Americanization. (Hennen, 1998). But coal conflict intensified in southern West Virginia and Eastern Kentucky, and violence erupted in those areas. (Lee, 1969; Corbin, 1981; and Hevener, 1978).

Within the coal industry, a further economic sector division occurred. Federal coal price legislation caused a shift in buying habits away from middle operators to the coal giants. Those industrialized giants, however, did not absorb the unemployment that flowed from the abandonment of mines by the small and middle operators. Following the closure of most smaller mines, a later price differentiation of ten cents per ton of coal was placed into the federal 
regulations, but that price differential was applied too late to respond to the outflow of business from small and middle operators to larger enterprises when those smaller operators could not compete with lesser grade coal at one fixed, higher price, and big capital backed by the state prevailed.

Federal Regulations governing the processing and sale of coal had mandated that all coal be sold at the same price, meaning that there was no demand for coal of lower quality when consumers, whether individual or industrial, would have to pay the same price regardless. Here we see scaled state actions impacting capital long before the advent of mountaintop removal. Middle operators were put out of business by the state's economic regulation of the industry to the benefit of capital. Capital accumulation in the hands of big capital resulted as the larger operators absorbed the benefits and profit of smaller operators and experienced a much needed capital expansion in that regard.

Greater industrialization of the coal industry also led to a dramatic reduction in costs of production for the largest producers and the concomitant elimination of thousands of mining jobs. Practices which sacrificed the environment and the livelihoods of Appalachians, sanctioned by the state, as well practices which sacrificed their land, also sanctioned by the state, abounded, and the mining industry in Appalachia flourished. Coal production would remain isolated in the central Appalachian states because of resource unavailability or, at the least, limitation in other areas. As a result, while the West Virginia coal fields were experiencing their height, southern Appalachia had not yet been economically impacted to the same degree by industrial change. Throughout the process stark economic, political, environmental, legal, and social developments, all occurring during this period, acted as the shifting foundation for completion of capitalist change. (Erikson, 1976). 
Coal increased the pace of economic development, aided by federal scale interventions that benefitted capital. Coal development on Scotts Run flourished rapidly starting with the mining of the first ton of coal there. By 1917, the price of coal had stabilized when the Federal Fuel Administration set the price for soft coal at $\$ 2.58$ per ton. (Eller, 1982). This influence by the state on the market, referenced above, marks the first state intervention into the capitalist process noted here. If we are to adopt Smith's traditional state scaling, this intervention took place at the national scale.

Like the remainder of West Virginia, when coal development on Scotts Run saw its greatest growth it was fueled by demand resulting from World War I. The industry also expanded so rapidly because of incentives to take coal to market at low rates offered by the railroads to encourage an increase in coal traffic on the rails. (Thomas, 1998). Any operator who could get coal cars could sell his coal. (Eller, 1982, p. 155). By 1920, the wartime Federal Fuel Administration released price controls, and at times coal sold at or near fourteen dollars per ton, a comparatively very high price which marked the second intervention at this same federal scale. Later the federal government again would institute a third intervention in the form of price controls, and the price of coal again would plummet. (Eller, 1982, p. 156). Smaller mines often operated at peak production during times of high demand, but when the price of coal decreased they often closed down, and economic growth correspondingly slowed. (Eller, 1982, p. 153). After 1927 prices would fall, not because of regulation, but with demand, and the period of more rapid industrialization would end in favor of a return to slower advances. (Eller, 1982, p. 157).

Wages also impacted economic conditions over time, again aided by federal interventions. Non-union competition made operation of union mines difficult, labor relations were strained, and violence erupted in the West Virginia coal fields. (Lee, 1969). Demand for 
coal decreased during the 1920's; production and wages decreased with it. The miners suffered. By 1927, miners were making less than their 1917 wages. Between 1923 and 1927 over 200,000 miners left the coal fields. (Eller, 1982). Per capita wages of miners dropped from \$851 in 1923 to $\$ 235$ by 1933 . These changes compounded already poor economic and social conditions. Likewise, mechanization of the coal industry resulted in the even more lost jobs and the attendant temporal decline of industrialization. Industries such as textiles and timber would experience similar uneven progressions (Lewis, 1998, and Williams, 2001).

Regardless, coal continue to be king in Appalachia as the deep mining and surface mining of the state continued, largely in the hands of large operators, through the turn of the millennium. But a new development in coal was just around the corner. The time had arrived for the introduction of mountaintop removal. With the introduction of mountaintop removal we see the introduction of state spatial practices at scales other than the federal regulatory scale, illustrating flexible rescaling at work in Appalachia again for another land acquisition.

If we return to Lewis's theory that Appalachian industrialization is an ongoing process, we can continue to examine that industrialization as it reached a point of crisis when traditional mining in West Virginia declined and when operators began to fear the exhaustion of resources attainable by deep mining. We then see the emergence, through state spatial practices that amount to heavy facilitation by the state, of another dispossession of land in the form of the relatively new practice of mountaintop removal. This dispossession is an example of the accumulation by dispossession that Harvey noted as distinguishable from original or primitive accumulation by its role in ongoing dispossession meant to avert capitalist crisis.

In its simplest explanation, mountaintop removal is a form of surface mining. The surface of a mountaintop is "removed" to allow for the extraction of a coal seam at the 
surface. The land above the coal seam is moved to an adjacent valley, and the valley is filled in with the land removed from the top of the seam. The process usually occurs through high impact blasting. Often more than 100 meters of dirt and rock are removed from the top of the mountain with explosives to allow the exposure and extraction of the coal seam. (Burns, 2007).

Mountaintop removal has been the subject of significant public and legal opposition. (House and Howard, 2009). State spatial practices at the federal level that changed existing federal legislation allowed the process in the first instance, so like traditional mining, initial state involvement begins at the federal scale. In 1977, the enactment of the Federal Water Pollution Control Act, commonly known as the Clean Water Act, amounted to a spatial practice by Congress at the federal scale. The stated purpose of the action was to "restore and maintain the chemical, physical, and biological integrity of the Nation's waters. (Federal Water Pollution Control Act, 1977). The Clean Water Act allows the obtaining of a permit to place "fill material" into waters of the United States, provided that the primary purpose of the "filling" was not for waste disposal. (Federal Water Pollution Control Act, 1977). As written, therefore, the Clean Water Act prohibited Mountaintop removal, because no valley fills were allowed for disposal of Mountaintop removal “waste.” However, in 2002, the Army Corps of Engineers which issues the permits for the dumping of "fill material” into American waterways, at the behest of the Bush administration, absent congressional approval, which was not required for such amendment, changed the longstanding definition of "fill material," and included or redesignated mining residues as a defined "fill material” rather than waste, officially sanctioning mountaintop removal and flexibly rescaling to take the power away from the Clean Water Act and laterally shifting power, bringing its control under the umbrella of the Army Corps of Engineers. 
When the Army Corps of Engineers changed the definition of “fill material” we see an example, for the first time of lateral flexible rescaling. The Corp operates, as does Congress, at the federal scale, but the actions of Congress would have disallowed mountaintop removal mining. Capital needed mountaintop removal mining to spur the coal industry, and help for capital came not from a scalar shift up or down, but from a flexible lateral rescaling. Power remained at the federal scale but moved from the legislative to the executive branch.

Since that time, the Appalachia Restoration Act has been introduced in the Senate in an attempt to restore the original meaning of fill material in the Clean Water Act and to return mining debris to the category of waste, as well as to shift power back laterally from the executive to the legislative branch. (Appalachian Restoration Act). The Appalachian Restoration Act suggests a definition of fill material be added to the Clean Water Act, which would include an exclusion from fill material of "the disposal of excess spoil material (as described in Section 515(b)(22) of the Surface Mining Control and Reclamation Act...” (Appalachian Restoration Act).

The state is spatially active in other areas on mountaintop removal than just permitting. After active mining has been completed federal law requires that the disturbed areas of the mining operation by "reclaimed." This requirement originates out of the Surface Mining Control and Reclamation Act of 1977(SMCRA), referenced above. (Surface Mining Control and Reclamation Act, 1977). The Act was enacted at a time when mountaintop removal was not yet in practice. Ultimately the Act allowed for two dispossessions of land: the dispossession of actual land which is mined as well as the dispossession of attendant resources through adjacent valley fills and through use or consumption or destruction of public water resources. There is one federal scale state spatial practice at work that results in two spatial impacts that benefit 
capital.

The Environmental Protection Agency estimates that by 2012, two decades of mountaintop removal will have destroyed or degraded 11.5 percent of the forests in West Virginia, Kentucky, Virginia, and Tennessee, an area larger than Delaware, and that mountaintop removal waste will have buried more than 1,000 miles of streams. (Mountaintop Mining Programmatic EIS, 2005). Smithsonian author John McQuaid observed "I've reported on devastation around the world — from natural disasters such as Hurricane Katrina, to wars in Central America and the Middle East, to coastlines in Asia degraded by fish farming. But in the sheer audacity of its destruction, mountaintop coal removal is the most shocking thing I've ever seen. Entering a mountaintop site is like crossing into a war zone.” (McQuaid, 2009). Facts like these and the opponents they create caused the shift away from lateral rescaling that becomes evident when we examine challenges to mountaintop removal.

Political and legal opposition to the new method of mining developed, but the state continued to flexibly rescale as necessary. McQuaid notes the state level support for capital that would underlie challenges as that scale, stating that "West Virginia's political establishment has been unwavering in its support for the coal industry.” (McQuaid, 2009). West Virginia Governor Joe Manchin also spoke on the state scale support of the industry stating at a Coal Association meeting "Government should be your ally, not your adversary," illustrating flexible rescaling at work to rescale to the state scale from the federal scale with permitting control then in the hands of the Army Corps of Engineers to allow such dispossessions. (McQuaid, 2009).

In 1990, at the federal level, amendments to the Clean Water Act established a requirement that there be "no net loss of wetlands." (Federal Water Pollution Control Act, 1990). In conjunction with mountaintop removal, to valley fill, a coal company must obtain a permit 
from the United States Army Corps of Engineers. The Corps is charged with evaluating the environmental impact as well as any required remedial action as a result thereof before issuing such a permit. The corresponding National Environmental Policy Act can also require a detailed environmental impact statement to be completed before a permit is issued. (National Environmental Policy Act, 1969). But coal companies have obtained the required permits without the Corp actually evaluating possible environmental impacts. These instances have been challenged in West Virginia in front of Judge Chambers of the United States District Court for the Southern District of West Virginia. Ohio Valley Environmental Coalition, et al. v. U.S. Army Corps. of Engineers, et al.

In that matter Plaintiffs, the Ohio Valley Environmental Coalition, requested that the Federal District Court find that the U.S. Army Corps of Engineers violated the Clean Water Act and the National Environmental Policy Act by issuing four permits to fill headwater streams in conjunction with mountaintop removal coal mining. Ohio Valley Environmental Coalition, et al. v. U.S. Army Corps. of Engineers, et al. In a 2007, decision in that case, Judge Chambers' opinion amounted to a state spatial practice at the state scale. The opinion stated that "the Corps has failed to take a hard look at the destruction of headwater streams and failed to evaluate their destruction as an adverse impact on aquatic resources in conformity with its own regulations and policies," but the opinion allowed ongoing mountaintop removal projects to proceed. $\underline{\text { Ohio }}$ Valley Environmental Coalition, et al. v. U.S. Army Corps. of Engineers, et al. The case was appealed the case to the historically conservative Virginia-based United States Court of Appeals for the Fourth Circuit, at yet another scale - the regional scale- which had already acted to allow mountaintop removal mining in other instances.

Another Southern District Judge, The Honorable Charles H. Haden II, after 
visiting a mountaintop removal mining site in southern West Virginia, noted:

[M]ined sites were visible from miles away. The sites stood out among the natural wooded ridges as huge white plateaus, and the valley fills appeared as massive, artificially landscaped stair steps. Compared to the thick hardwoods of surrounding undisturbed hills, the mine sites appeared stark and barren and enormously different from the original topography.

Bragg v. Robertson. Nonetheless, mountaintop removal mining continues, aided by the continual shifts in power up and down between the federal, regional, and state scales and laterally within scales that remain a part of the state's active spatial practice of flexible rescaling capable of advancing the interests of capital.

"Industrialization has integrated the mountains into the dominant economy of the country as a whole, and it has rendered the region increasingly subject to the fluctuations of the national market system." (Eller, 1982, p. 227). As a result, what started as a local industry has fallen under national control as flexible scaling revealed itself within the mining industry. Despite withdrawal of consent and state support during the union battles of the early twentieth century, the state has now reappeared as capital’s ally as flexible rescaling shifts power again. 


\section{Chapter 8 \\ Conclusions}

This dissertation has developed the new concept of flexible rescaling as a means of attempting to fill the prior gap in the literature left by the under-theorized role of the state in uneven development. As a researcher I admittedly have been influenced by my own liberal social tendencies, but what has emerged: evidence of and conceptualization and theoretical development of the active and deliberate state spatial practice of flexible rescaling that is employed by the state to impact uneven development to the benefit of capital absent a need for a formal restructuring of power or of the state which might result in resistance if not crisis, advances the theory of the state’s role in uneven development.

I chose the examples that illustrate the theory, because I thought they would provide a cohesiveness. This cohesiveness is achieved, because the examples are all from within Appalachia and the examples are all based in land practices. Returning to dialectics, these are the two most important identities of the examples which ultimately allow their differences to be better understood.

In choosing the examples to illustrate the theory it was also important to me to choose examples that impacted both accumulation by dispossession and accumulation by expanded reproduction. The eminent domain examples here meet that requirement. The example of high voltage power transmission lines and the attendant dispossessions demonstrates more traditional accumulation by dispossession, and the example of mountaintop removal, while still illustrative of accumulation by dispossession of the commons, is more demonstrative of a state spatial practice that allows accumulation by expanded reproduction, in that case mining.

Finally, in choosing examples it was important to me to choose examples that would illustrate conventional expansion for expansion's sake, illustrated by the transfer of land 
to capital for power line construction, and that would illustrate expansion as a means to avert a capital crisis, illustrated by mountaintop removal.

Recent events have made me consider research regarding the flexible rescaling brought about by the 2010 BP gulf oil spill where, to me, flexible rescaling can already be seen. Federal government allocation of funds to assist victims of the spill in lieu of that aid coming from BP amounts to a spatial practice that results in a redistribution of resources that benefits capital. Even if some individuals or entities receive relief from any state fund that is created, if they eventually become stakeholders in an action against BP, then BP will legally be entitled to a credit set-off for any monies paid to the victims to make them whole. The law acts to prevent a windfall, and, in doing so, it flexibly rescales power to benefit capital.

In examining what this dissertation is and is not, I return to my acknowledgment that the dissertation was never meant to be a new comprehensive theory of the state or of uneven development. After using the theorizations to date, I am not convinced a completely new and comprehensive theory of either is needed, but, to be sure, such a theorization is a life's work, not a dissertation.

During my research I discovered that a transfer of power by the state in order to flexibly rescale can be accomplished not only by movement of power up and down through the system, but also through lateral rescaling- a type of flexible rescaling I had not considered when I set out to develop this theory and which was not included in my proposal. As I postulated before writing the dissertation, the ability inherent within the state to flexibly rescale results in a system where the state can employ the active spatial practice of rescaling to control uneven development to the benefit of capital. What I did not expect was for power to travel laterally with similar result, a discovery that I think advances the theory and proves its applicability and utility 
even more than I anticipated.

As a result, it is apparent that flexible rescaling occurs between and within scales. Within scales flexible rescaling occurs laterally, as was demonstrated with the case of mountaintop removal mining where changes between the legislative and executive policy at the federal level occurred. Between scales flexible rescaling occurs as anticipated, when power moves up and down between scales, best illustrated with examples that show appeals within the inherently stratified legal system at work to change policy to benefit capital.

Regardless of whether flexible rescaling is lateral or stratified, the active spatial practices of the state, through both action and decided inaction, amount to shifts in power that benefit capital and illustrate and develop the active spatial role of the state in impacting uneven development. The inherent flexibility within the system does not require a formal restructuring for either lateral or stratified shifts in power. As a result, flexible rescaling is a powerful tool by which the state actively engages in spatial practices that benefit capital and impact uneven development as a result.

During the research proposal I identified several questions which, looking back on my research to date, remain unanswered or lack full development. Some are explicitly noted within the dissertation, such as the benefit of additional research into ruling class control of the media and propaganda and what role that control plays in securing legitimation and/or consent, as well as how that control itself is fostered by the state as a secondary aspect of flexible rescaling.

Other questions emerged when examining the conceptual development. During the actual research it became apparent to me that more in depth case studies might allow the dialectical method to reveal itself better and might allow for a better understanding of the 
interconnections between the state's actions and capital. More in depth case studies might also allow time to address some of the issues identified previously in my research proposal which were not answered or parsed out to my satisfaction in this dissertation. For example, while my proposal postulated that Harvey's theory of imperialist practices could be expanded from his chosen international scale to the intranational scale, ultimately this dissertation spent more time developing the new concept of flexible rescaling than it did attempting to alter the scale of Harvey's theory and testing whether such alternation survives theoretically. While the dissertation conducts examination on an intranational scale and recognizes that the engines that drive power processes on that intranational scale are money, productive capacity, and regulatory power, only regulatory power is examined at any length herein.

The time required over the past six years to read, research, and, most importantly, synthesize a new conceptual development like flexible rescaling prevented the type of in depth case study that might later reveal more about the theory. Theoretical development was also necessary before such a detailed case study could be undertaken. The process of developing the theory and exemplifying it further refined the theory making it more appropriate for consideration as part of an in depth case study going forward than it might have been for this dissertation.

Additionally, the theory developed explains how the state shifts power to benefit capital, but there is a Marxist analysis waiting in the wings as to why the state shifts power to benefit capital; the inclusion of Massey’s work and Howitt's work on connections and relations was used and useful in the process of the theoretical development but could be revisited as the theory is tested and developed further; and the role of consent as well as identity formation could be further developed by examining the impact of consent, or lack thereof, on additional spatial 
practices and the impact of flexible rescaling on level and nature of consent.

The use of dialectics in the dissertation proved to be a good choice, but I struggled with how explicit to make the appearance and use of its abstractions so as to not become too positivist in my analysis. While dialectics can itself appear formulaic and over-structured with its lists of relations, modes of abstraction, levels of generality, and laws of the dialectic, at the same time- to me- it seems almost too flexible and hard to pin down precisely, because it is designed to reflect the changing nature of things and the ever-shifting relationships between them. Move your focus ever so slightly and your whole analysis can change. Keep your focus steadfast and risk defeating the point of a relational analysis. Deciding that Ollman himself did not make explicit reference to the methodology of dialectics with frequency in his examples, I decided to allow the abstractions to reveal themselves except where I could not resist including a strong example of dialectics at work or except where I felt the need to be explicit in order to justify the use of dialectics or to illustrate the benefit of the use of dialectics.

Hopefully the development of the new theory of flexible rescaling adds significantly to the geographic literature to date on the state's spatial role in uneven development and to the theory of uneven development generally. Hopefully additional research will reveal even more about the role the state plays and why. 


\section{BIBLIOGRAPHY}

\section{Academic References}

Blomley N (1988) Law and the local state: Enforcement in action. Transactions of the Institute of British Geographers 13(2), 199-210

Brenner N (1997) Global, fragmented, hierarchical: Henri LeFebvre's geographies of globalization. Public Culture 10(1), 135-167

Brenner N (1997) State territorial restructuring and the production of spatial scale: Urban and regional planning in the Federal Republic of Germany. Political Geography 16(4), 273-306

Brenner N (1998) Between fixity and motion: Accumulation, territorial organization and the historical geography of spatial scales. Environment and Planning D: Society and Space 16, 459-481

Brenner N (2000) The urban question as a scale question: Reflections on Henry Lefebvre: Urban theory and the politics of scale. International Journal of Urban and Regional Research 24(2),361-378

Brenner N (2004) New State Spaces. Oxford University Press: Oxford

Burns, S (2007) Bringing Down the Mountains: the Impact of Mountaintop Removal on Southern West Virginia Communities. Morgantown: West Virginia University Press

Claeys E (2004) Public use limitations and natural property rights. 2004 Mich. St.L. Rev. 1

Corbin D (1981) Life Work and Rebellion in the Coal Fields. University of Illinois Press: Urbana

Cox K (2004) Globalization and the politics of local and regional development: The question of convergence. Transactions of the Institute of British Geographers 29, 179194

Cox K and Mair A (1989) Levels of abstraction in locality studies. Antipode 21, 121-132

Delaney D (2001) Making nature/marking humans: Laws as a site of (cultural) production. Annals of the Association of American Geographers 91(3), 487-503

Dunaway W (1996) First American Frontier: Transition to Capitalism. University of North Carolina Press: Chapel Hill 
Dunaway W (1996) First American Frontier: Transition to Capitalism. University of North Carolina Press: Chapel Hill

Eller R (1982) Miners, Millhands, and Mountaineers. University of Tennessee Press: Knoxville

Erikson K (1976) Everything in its Path. Simon and Schuster: New York

Fones-Wolf K and Lewis R (2002) Transnational West Virginia. West Virginia University Press: Morgantown

Forgacs D (ed.) (2000) The Antonio Gramsci Reader: Selected Writings 1916-1935. New York University Press: New York

Frank, A (1967) Capitalism and Underdevelopment in Latin America. New York: Monthly Review Press.

Harvey D (1987) Flexible accumulation through urbanization: Reflections on "postmodernism" in the American city. Antipode 19(3), 260-86

Harvey D (2003) The New Imperialism. Oxford University Press: Oxford

Harvey D (1985) The Geopolitics of Capitalism. Social Relations and Spatial Structures. St. Martin's Press: New York

Harvey D (1989) The Condition of Postmodernity: An Enquiry into the Conditions of Cultural Change. Blackwell: Oxford

Harvey D (2006) Spaces of Global Capitalism: Towards a Theory of Uneven Geographical Development. Oxford University Press: Oxford

Hennan J (1998) The Americanization of West Virginia. University of Kentucky Press: Lexington

Hevener J (1978) Which Side Are You On? University of Illinois Press: Chicago

House S and Howard J, eds. (2009) Something's Rising: Appalachians Fighting Mountaintop Removal. University of Kentucky Press: Lexington

Howitt R (2003) Scale, in A Companion to Political Geography. Blackwell: Oxford Lee H (1969) Bloodletting in Appalachia. West Virginia University Press: Morgantown

Lewis R (1998) Transforming the Appalachian Countryside. University of North Carolina Press: Chapel Hill 
Mann M (2003) The autonomous power of the state: Its origins, mechanisms and results. State/Space: A Reader. Blackwell: Oxford

Massey D (1995) Spatial Divisions of Labor: Social Structures and the geography of Production, 2ed. Routledge: New York

McQuaid J (2009) Mining the mountains. Smithsonian 39 (10): 74-85

Merrifield A (1993) Place and space: A LeFebvrian reconciliation. Transactions of the Institute of British Geographers 18, 516-531

Milliband R (1969) The State in Capitalist Society. Verso: London

Ollman B (1993) Dialectical Investigations. Routledge: New York

Ollman B (2003) Dance of the Dialectics. University of Illinois Press: Chicago

Poulantzas N (2001) State, Power, and Socialism. Verso: London

Poulantzas N (2008) The Poulantzas Reader: Marxism, Law and the State. Verso: London

Roy A (2001) Power Politics. South End Press: Cambridge

Salstrom P (1997) Appalachia's Path to Dependency. University of Kentucky Press: Lexington

Sayer A (2003) Long live post disciplinary studies! Sociology and the curse of disciplinary parochialism/imperialism. At http://www.comp.lancs.ac.uk/sociology/paper/ Sayer-Long-Live-Postdisciplinary-Studies.pdf. Date of last access: 4/22/06

Silvern S (2002) State centrism, the equal footing doctrine, and the historical-legal geographies of American Indian treaty rights. Historical Geography 30, 33-58

Smith N (1990) Uneven Development: Nature, Capital and the Production of Space, $2^{\text {nd }}$ ed. Blackwell: Massachusetts

Smith N (1992) Geography, difference, and the politics of scale. Postmodernism and the Social Sciences. Macmillan: London

Smith N (2003) Remaking scale: Competition and cooperation in pre-national and postnational Europe. State/Space: A Reader. Blackwell: Oxford

Smith N (2005) The Endgame of Globalisation. Routledge: New York 
Swyngedouw E (1997) Neither global nor local "glocalization" and the politics of scale. Spaces of Globalization. Guilford: New York

Swyngedouw E (1997) Excluding the other: The production of scale and scaled politics. Geographies of Economies. Arnold: London

Thomas J (1998) An Appalachian New Deal. University of Kentucky Press: Lexington

Tuan Y (1977) Space and Place: The Perspective of Experience. University of Minnesota Press: Minneapolis

Williams J (1976) West Virginia: A History. W.W. Norton \& Co.: New York

Williams J (2001) Appalachia: A History. University of North Carolina Press: Chapel Hill

\section{Legal References}

Appalachian Restoration Act, Senate Bill 696

Berman v. Parker, 348 U.S. 26 (1954).

Bragg v. Robertson, 54 F. Supp.2d 635, 646 (S.D.W. Va. 1999).

Dominion Post, Leaving a TRail, April 16, 2008

Energy Policy Act (2005) 42 U.S.C. §15801

Federal Question Jurisdiction 28 U.S.C. §1257(a)

Federal Water Pollution Control Act (1977) 33 U.S.C. §1362

Federal Water Pollution Control Act Amendments (1990) 42 U.S.C. §85

Hawaii Housing Authority v. Midkiff, 467 U.S. 229 (1984).

Kelo v. City of New London, 545 U.S. 469 (2009)

National Environmental Policy Act (1969) 42 U.S.C §4321

National Industrial Recovery Act (1933) 15 U.S.C. §703

National Labor Relations Act (1935) 29 U.S.C. §§151-169 
Ohio Valley Environmental Coalition, et al. v. U.S. Army Corps of Eng., et al., Civil Action No. 3:05-0784

Poletown Neighborhood Council v. City of Detroit, 304 N.W.2d 455 (Mich. 1981).

Surface Mining Control and Reclamation Act (1977) 30 U.S.C. §§1234-1328

United States Const., Amend. V, Takings Clause

United States Environmental Protection Agency "Mountaintop Mining/Valley Fills in Appalachia: Final Programmatic Environmental Impact Statement. (October, 2005)

West Virginia Public Service Commission, Case No. 07-0508-E-CN, TRans-Allegheny Interstate Line Company, Application for a Certificate of Convenience and Necessity and related documents. 